\title{
Geologic and Geochronologic Studies of the Early Proterozoic Kanektok Metamorphic Complex of Southwestern Alaska
}

By Donald L. Turner, Robert B. Forbes, John N. Aleinikoff, Ian McDougall, and Carl E. Hedge

Preface by Frederic H. Wilson, Paul W. Layer, and Chad P. Hults

Open-File Report 2009-1248

U.S. Department of the Interior

U.S. Geological Survey 


\section{U.S. Department of the Interior KEN SALAZAR, Secretary}

\section{U.S. Geological Survey Marcia K. McNutt, Director}

U.S. Geological Survey, Reston, Virginia: 2009

For product and ordering information: World Wide Web: http://www.usgs.gov/pubprod

Telephone: 1-888-ASK-USGS

For more information on the USGS - the Federal source for science about the Earth, its natural and living resources, natural hazards, and the environment:

World Wide Web: http://www.usgs.gov

Telephone: 1-888-ASK-USGS

Suggested citation:

Turner, D.L., Forbes, R.B., Aleinikoff, J.N., McDougall, lan, and Hedge, C.E., 2009, Geologic and geochronologic studies of the early Proterozoic Kanektok metamorphic complex of southwestern Alaska, with a preface by Wilson, F.H., Layer, P.W., and Hults, C.P.: U.S. Geological Survey Open-File Report 2009-1248, 45 p. [http://pubs.usgs.gov/of/2009/1248/.

Any use of trade, product, or firm names is for descriptive purposes only and does not imply endorsement by the U.S. Government.

Although this report is in the public domain, permission must be secured from the individual copyright owners to reproduce any copyrighted material contained within this report. 


\section{Contents}

Preface
History of the Manuscript
New Results and Commentary
References Cited in Preface
Abstract
Introduction
Geology
Regional Geology and Tectonic Setting
Structure
Petrology
Suggested Structural Model
Geochronology
Evidence for Excess ${ }^{40}$ Ar

\section{Figures}

Figure I-1. Simplified geologic map showing collection localities for samples analyzed by Turner and others.

Figure I-2. ${ }^{40} \mathrm{Ar} /{ }^{39} \mathrm{Ar}$ age spectrums for samples DT 76-69A and DT 76-70

(2 analyses)...

Figure 1. Tectonic map of Alaska and adjacent areas in Canada, showing 8 localities of Precambrian rocks discussed in this report

Figure 2. Geologic map of the Kanektok complex and associated rocks (from Hoare and Coonrad, 1979)

Figure 3. Geologic traverse map of the southwestern part of the Kanektok complex based on field work by Forbes and Turner in 1975

Figure 4. Diagrammatic structure section across Kanektok complex.

Figure 5. Histogram of 77 apparent ${ }^{40} \mathrm{Ar} /{ }^{40} \mathrm{~K}$ mineral ages from all major outcrop areas of the Kanektok complex.

Figure 6. ${ }^{40} \mathrm{Ar} /{ }^{39} \mathrm{Ar}$ incremental heating release spectrum for DT 75-72 biotite $\left({ }^{40} \mathrm{Ar} /{ }^{40} \mathrm{~K}\right.$ total fusion age 2.5 b.y. $)$

Figure 7. ${ }^{40} \mathrm{Ar} /{ }^{39} \mathrm{Ar}$ age spectrum of DT $75-70$ biotite ${ }^{40} \mathrm{Ar} /{ }^{39} \mathrm{Ar}$ total fusion age $487 \mathrm{Ma})$

Figure 8. ${ }^{40} \mathrm{Ar} /{ }^{39} \mathrm{Ar}$ age spectrum of DT $75-69$ hornblende $\left({ }^{40} \mathrm{Ar} /{ }^{39} \mathrm{Ar}\right.$ total fusion age $478 \mathrm{Ma})$

Figure 9. ${ }^{40} \mathrm{Ar} /{ }^{39} \mathrm{Ar}$ age spectrum of DT $75-76$ hornblende $\left({ }^{40} \mathrm{Ar} /{ }^{39} \mathrm{Ar}\right.$ total fusion age $1124 \mathrm{Ma})$ 
Figure 10. $\mathrm{Rb}$-Sr diagram for 13 whole-rock samples of Kanektok core zone amphibolite facies rocks collected along a 2.5 mile traverse in the Thumb Mountain area

Figure 11. Concordia plot of 3 size fraction splits of zircons from core zone

orthogneiss sample DT 75-86 from the Thumb Mountain area. 42

\section{Tables}

Table I-1. Analytical data for samples from the Kanektok Metamorphic Complex ................ 4

Table 1. Analytical data for K-Ar analyses of samples from Kanektok complex ................. 19

Table 2. Analytical data for ${ }^{40} \mathrm{Ar} /{ }^{39} \mathrm{Ar}$ age spectra.......................................................... 29

Table 3. Analytical data for $\mathrm{Rb}$-Sr analyses of whole-rock samples from Kanektok complex core near Thumb Mountain 38

Table 4. $\mathrm{U}, \mathrm{Th}$, and $\mathrm{Pb}$ isotopic data for zircon and sphene from quartz monzonite orthogneiss near Thumb Mountain 


\title{
Geologic and Geochronologic Studies of the Early Proterozoic Kanektok Metamorphic Complex of Southwestern Alaska
}

\author{
By Donald L. Turner ${ }^{1}$, Robert B. Forbes ${ }^{1}$, John N. Aleinikoff ${ }^{2}$, Ian McDougall ${ }^{3}$, and \\ Carl E. Hedge ${ }^{2}$ \\ Preface by Frederic H. Wilson ${ }^{4}$, Paul W. Layer ${ }^{5}$, and Chad P. Hults ${ }^{4}$ \\ ${ }^{1}$ Geophysical Institute, University of Alaska, Fairbanks, Alaska, USA \\ ${ }^{2}$ U.S. Geological Survey, Denver, Colorado, USA \\ ${ }^{3}$ Research School of Earth Sciences, Australian National University, Canberra, ACT, Australia \\ ${ }^{4}$ U.S. Geological Survey, Anchorage, Alaska, USA \\ ${ }^{5}$ Department of Geology and Geophysics, University of Alaska, Fairbanks, Alaska, USA
}

\section{Preface}

\section{History of the Manuscript}

This Open-File Report makes available a valuable set of geochronological data that were produced more than 25 years ago. In the early 1980s, Donald L. Turner, Robert B. Forbes (since deceased), John N. Aleinikoff, Ian McDougall, and Carl E. Hedge wrote a report about their geochronologic studies of the Kanektok metamorphic complex, a terrane of high-grade metamorphic rocks in the Goodnews Bay quadrangle of southwest Alaska. The report was approved for publication in 1982, but unaccountably was never completed. The geochronological data from the manuscript has been in the "gray literature" for many years and we felt it important that the data and manuscript be made available for future studies as the data and report are the most extensive and detailed available on the metamorphic complex. We thank Don Turner and John Aleinikoff for permission to publish this manuscript and important data.

At the time of the writing of the original manuscript, Hoare and Coonrad (1979) informally named the metamorphic rocks the Kanektok metamorphic complex; the rocks were later assigned to the Kilbuck terrane (Jones and others, 1981), another informal designation. The rocks were originally mapped by Hoare and Coonrad $(1959,1961)$ who later revised their mapping (Hoare and Coonrad, 1978). On the basis of the high metamorphic grade and the belief that the rocks of the complex were overlain by Devonian to Ordovician limestone, Hoare and Coonrad $(1959,1961)$ proposed a Precambrian age for these rocks. During the field mapping leading to Hoare and Coonrad's 1978 map, D.L. Turner and R.B. Forbes began studies of the metamorphic complex. Turner and Forbes' mapping and extensive sampling of the rocks provide the basis for this report. Turner and Forbes confirmed the Precambrian age of the metamorphic rocks, but found that the geochronologic data was complex and difficult to interpret. Originally, conventional K-Ar methods were used, supplemented by a suite of samples analyzed using the $\mathrm{Rb} / \mathrm{Sr}$ technique, and a few samples dated by the $\mathrm{U} / \mathrm{Pb}$ technique. However, many of the K-Ar samples yielded discordant ages when multiple mineral phases were dated. A few samples were also dated using the then new ${ }^{40} \mathrm{Ar} /{ }^{39} \mathrm{Ar}$ technique, which yielded spectra indicating disturbance. 
We have corrected a few typographical errors in the original manuscript and updated references that were in press at the time the manuscript was written. We have also re-checked the analytical data for the reported ages and made corrections from the original laboratory data where needed. We have also added a simplified geologic map derived from Wilson and others (2008) showing Turner's sample localities (fig. I-1). Also we have added, in brackets, the more formal Precambrian time subdivisions where appropriate.

\section{New Results and Commentary}

In the early 1990s, Paul Layer conducted additional ${ }^{40} \mathrm{Ar} /{ }^{39} \mathrm{Ar}$ analyses on a suite of samples to test the reliability of the conventional K-Ar analyses. An age spectrum on the oldest hornblende sample of Turner and others manuscript (sample DT 76-69a, table 1) confirmed the $1.78 \mathrm{Ga}$ age (sample DT 76-69a, table I-1, fig. I-2); the spectrum was flat and did not indicate argon loss. However, multiple analyses of a hornblende that had yielded a younger age, $915 \pm 27$ Ma, (sample DT 76-70, table I-1, fig. I-2) produced spectra indicating disturbance and indicated that the conventional $\mathrm{K}-\mathrm{Ar}$ ages were not correct due to resetting.

Three biotite samples, collected from a reported pyroxene granulite have dates reported in the Turner and others manuscript and yielded ages of about $2.5 \mathrm{Ga}$, which are the oldest ages ever determined in Alaska. Other samples from the metamorphic complex yielded $\mathrm{U} / \mathrm{Pb}$ zircon ages as old as $2.05 \mathrm{Ga}$; because of these zircon ages, Turner and his coworkers suggested that the biotite contains excess argon. Turner and others reported an ${ }^{40} \mathrm{Ar} /{ }^{39} \mathrm{Ar}$ analysis on one of the biotite samples (sample DT 75-72, table 2), which yielded what they reported as a "more-or-less normal" age spectra, which did not confirm the excess argon interpretation. However, Turner and others did report some interpretations from the literature of that period that suggested biotite may not be an appropriate mineral to analyze for excess argon. Unfortunately, no zircon was or has been dated from the granulite facies rocks. 


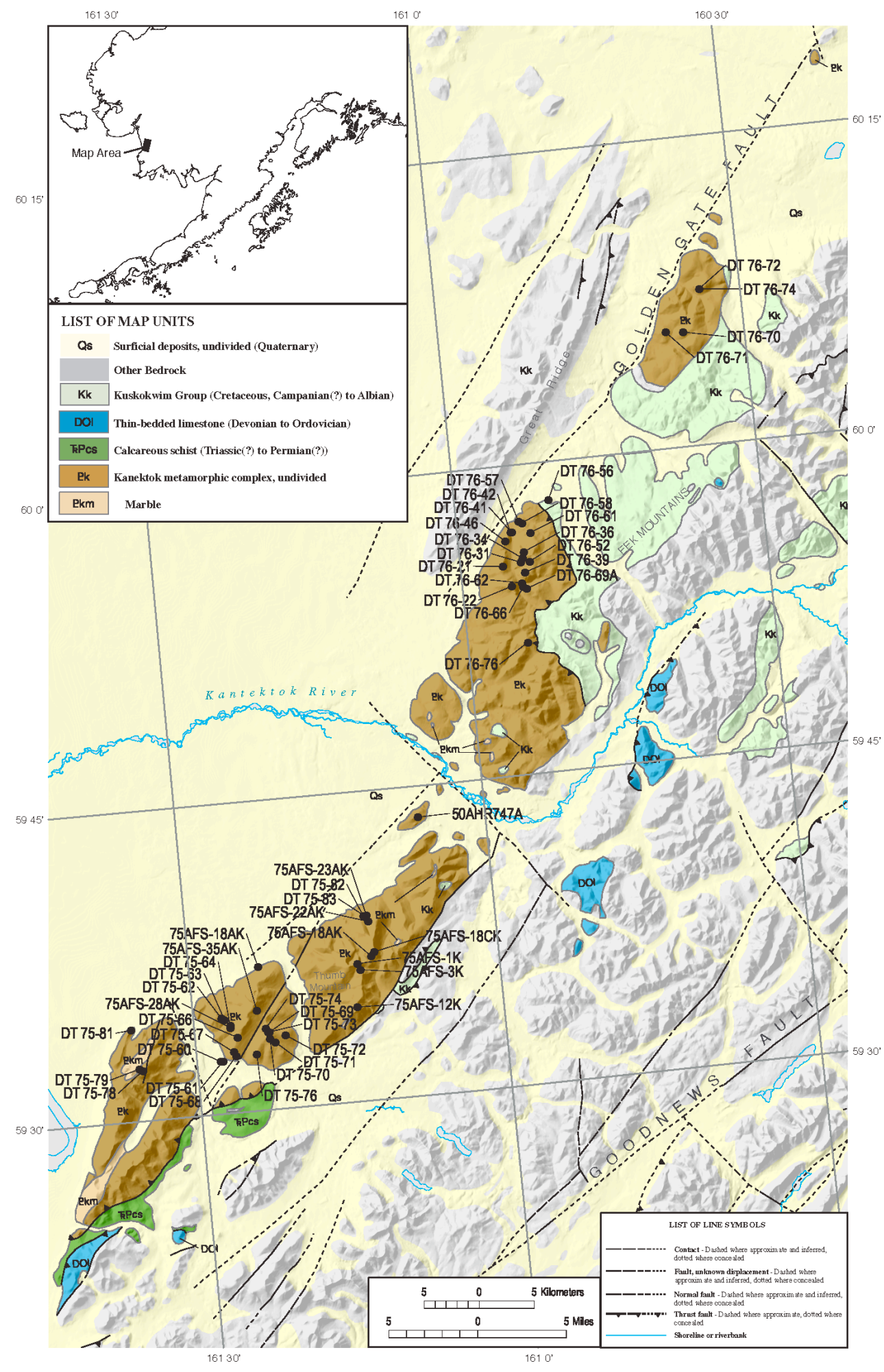

Figure I-1. Simplified geologic map showing collection localities for samples analyzed by Turner and others. 
Table I-1. Analytical data for samples from the Kanektok metamorphic complex (analyses by Paul Layer).

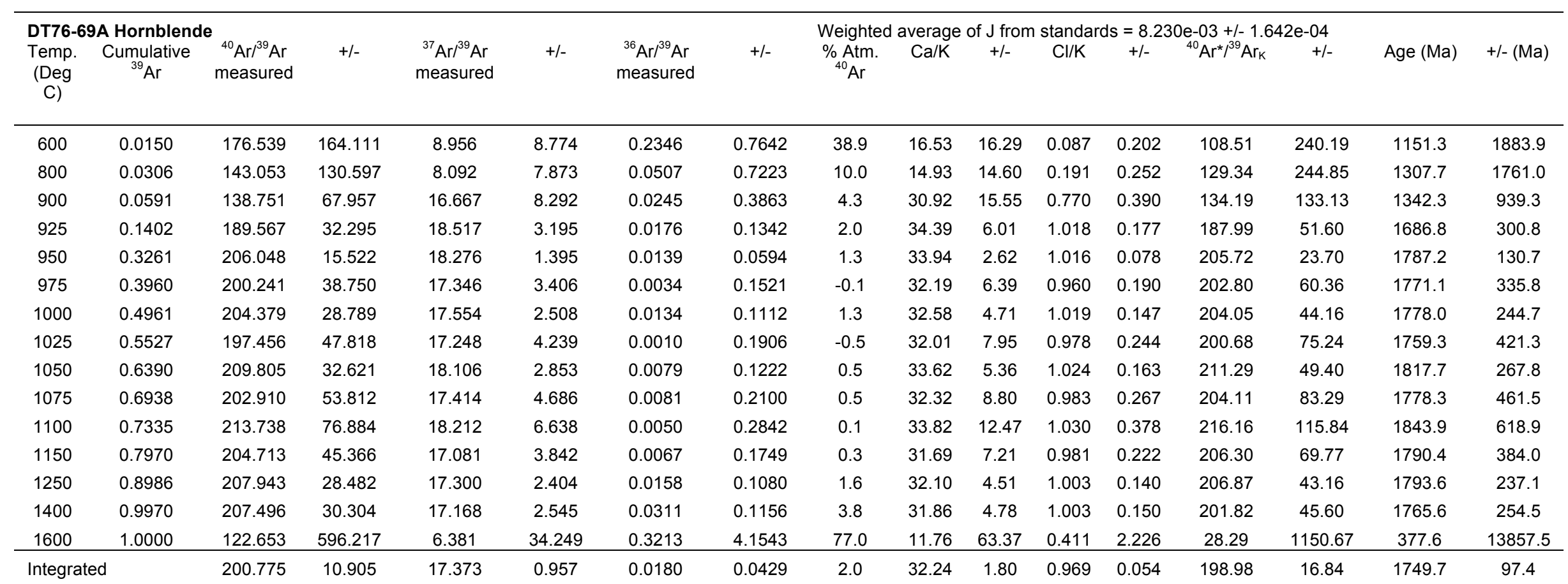


Table I-1. Analytical data for samples from the Kanektok metamorphic complex (analyses by Paul Layer). (cont.)

\begin{tabular}{|c|c|c|c|c|c|c|c|c|c|c|c|c|c|c|c|c|}
\hline \multicolumn{6}{|c|}{ DT76-70 Hornblende run \#1 } & \multirow[b]{2}{*}{$\begin{array}{l}{ }^{36} \mathrm{Ar} /{ }^{39} \mathrm{Ar} \\
\text { measured }\end{array}$} & \multirow[b]{2}{*}{$+/-$} & \multicolumn{7}{|c|}{ Weighted average of $\mathrm{J}$ from standards $=8.534 \mathrm{e}-03+/-7.746 \mathrm{e}-05$} & \multirow[b]{2}{*}{ Age (Ma) } & \multirow[b]{2}{*}{$+/-(\mathrm{Ma})$} \\
\hline $\begin{array}{l}\text { Temp. } \\
\text { (Deg } \\
\text { C) }\end{array}$ & $\begin{array}{l}\text { Cumulative } \\
{ }^{39} \mathrm{Ar}\end{array}$ & $\begin{array}{l}{ }^{40} \mathrm{Ar} /{ }^{39} \mathrm{Ar} \\
\text { measured }\end{array}$ & $+/-$ & $\begin{array}{l}{ }^{37} \mathrm{Ar} /{ }^{39} \mathrm{Ar} \\
\text { measured }\end{array}$ & $+/-$ & & & $\begin{array}{c}\% \text { Atm. } \\
{ }^{40} \mathrm{Ar}\end{array}$ & $\mathrm{Ca} / \mathrm{K}$ & $+/-$ & $\mathrm{Cl} / \mathrm{K}$ & $+/-$ & ${ }^{40} \mathrm{Ar}^{*} /{ }^{39} \mathrm{Ar}_{\mathrm{K}}$ & $+/-$ & & \\
\hline 500 & 0.0533 & 155.583 & 5.126 & 0.682 & 2.041 & 0.0933 & 0.0272 & 17.7 & 1.25 & 3.75 & 0.029 & 0.007 & 128.09 & 9.04 & 1332.6 & 66.5 \\
\hline 600 & 0.0653 & 48.726 & 7.133 & -1.989 & 9.076 & 0.0326 & 0.1201 & 20.1 & $\begin{array}{c}-3.64 \\
-\end{array}$ & 16.61 & 0.001 & 0.029 & 38.86 & 35.89 & 516.7 & 414.9 \\
\hline 675 & 0.0797 & 53.865 & 6.634 & -6.854 & 7.682 & -0.1475 & 0.1027 & -80.0 & 12.52 & 13.97 & 0.028 & 0.025 & 96.46 & 32.01 & 1083.6 & 270.3 \\
\hline 750 & 0.2073 & 43.895 & 0.601 & 6.481 & 0.851 & 0.0062 & 0.0112 & 3.1 & 11.94 & 1.57 & 0.108 & 0.003 & 42.69 & 3.38 & 560.5 & 38.1 \\
\hline 780 & 0.3695 & 49.128 & 0.535 & 7.096 & 0.676 & -0.0005 & 0.0089 & -1.4 & 13.08 & 1.25 & 0.120 & 0.003 & 50.00 & 2.70 & 641.1 & 29.1 \\
\hline 810 & 0.4914 & 57.093 & 0.822 & 8.134 & 0.898 & 0.0021 & 0.0118 & 0.0 & 15.00 & 1.67 & 0.116 & 0.003 & 57.37 & 3.60 & 718.9 & 37.2 \\
\hline 850 & 0.8315 & 80.209 & 0.422 & 8.130 & 0.322 & 0.0030 & 0.0042 & 0.4 & 15.00 & 0.60 & 0.099 & 0.001 & 80.32 & 1.33 & 941.8 & 12.1 \\
\hline 900 & 0.8883 & 89.049 & 2.735 & 9.646 & 1.925 & -0.0082 & 0.0252 & -3.5 & 17.81 & 3.58 & 0.090 & 0.007 & 92.76 & 8.02 & 1052.0 & 68.9 \\
\hline 950 & 0.9267 & 68.942 & 3.121 & 5.756 & 2.817 & -0.0030 & 0.0371 & -1.9 & 10.60 & 5.21 & 0.123 & 0.011 & 70.49 & 11.47 & 849.7 & 110.3 \\
\hline 1000 & 0.9418 & 80.805 & 9.387 & 5.298 & 7.227 & -0.0358 & 0.0954 & -13.6 & 9.75 & 13.35 & 0.093 & 0.026 & 92.07 & 30.24 & 1046.0 & 260.7 \\
\hline 1200 & 0.9915 & 77.530 & 9.353 & 7.899 & 8.036 & 0.0382 & 0.1095 & 13.8 & 14.57 & 14.90 & 0.109 & 0.028 & 67.14 & 33.51 & 817.2 & 328.0 \\
\hline 1600 & 1.0000 & 122.774 & 25.281 & 1.704 & 12.768 & 0.2078 & 0.1742 & 49.9 & 3.13 & 23.48 & 0.092 & 0.045 & 61.54 & 51.57 & 761.6 & 520.5 \\
\hline \multicolumn{2}{|c|}{ Integrated } & 71.269 & 0.596 & 6.909 & 0.539 & 0.0078 & 0.0072 & 2.5 & 12.73 & 1.00 & 0.100 & 0.002 & 69.77 & 2.23 & 842.8 & 22.3 \\
\hline
\end{tabular}


Table I-1. Analytical data for samples from the Kanektok metamorphic complex (analyses by Paul Layer) (cont.)

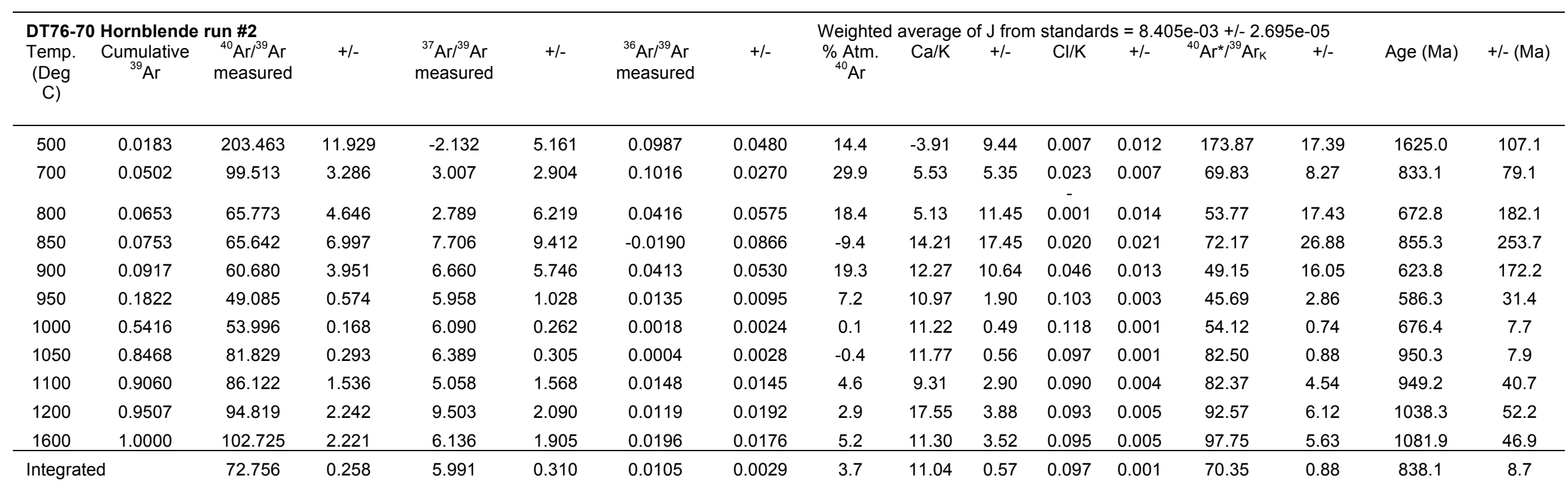



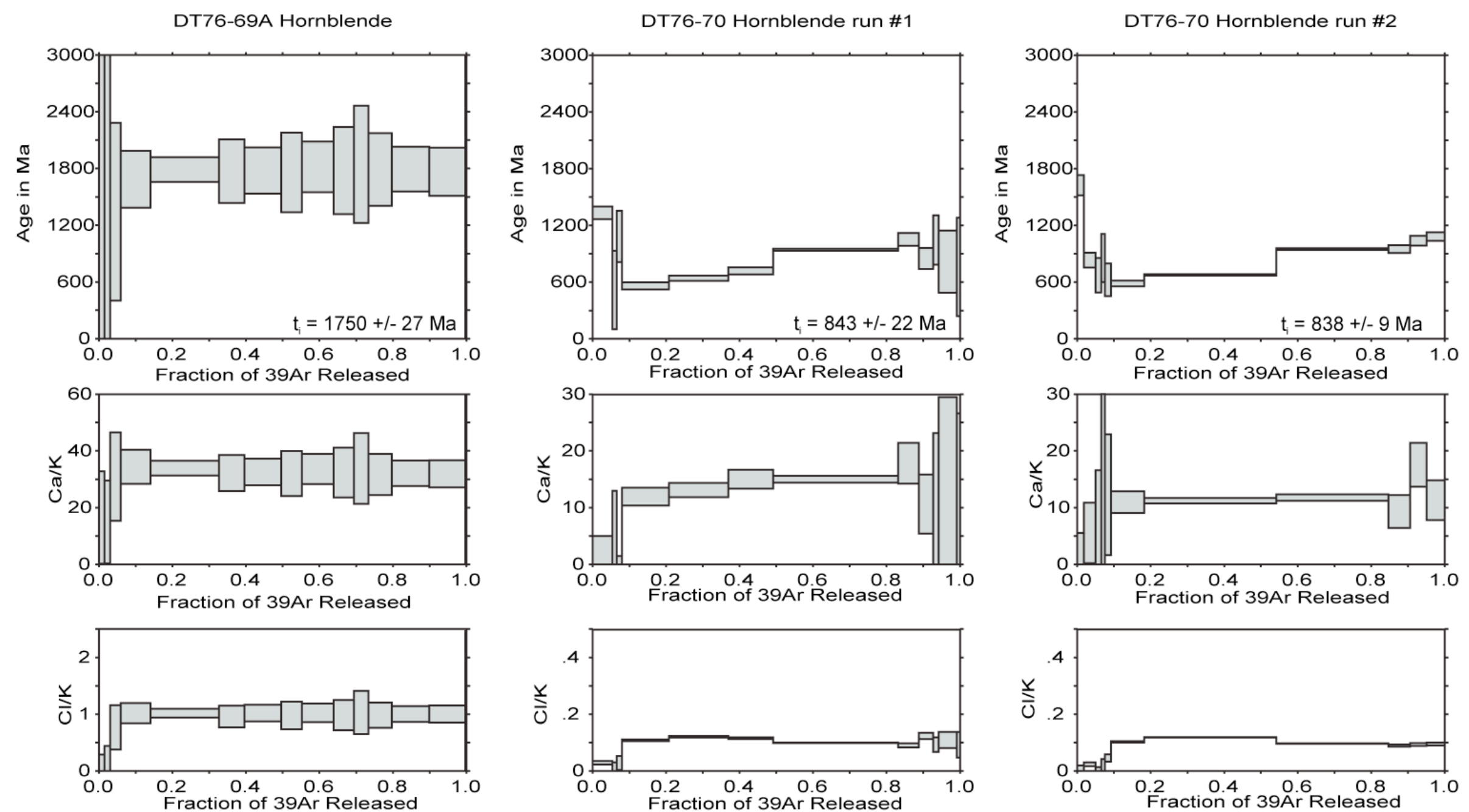

Figure I-2. ${ }^{40} \mathrm{Ar} /{ }^{39} \mathrm{Ar}$ age spectrums for samples DT 76-69A and DT 76-70 (2 analyses). Total fusion ages are 1,750 $\pm 27 \mathrm{Ma}, 843 \pm 22 \mathrm{Ma}$ and $838 \pm 9$ $\mathrm{Ma}$, respectively. Sample analyses by Paul Layer, Univ. of Alaska, in early 1990s. 
As discussed in Turner and others manuscript, the K-Ar ages range from about $130 \mathrm{Ma}$ to $2.5 \mathrm{Ga}$. Within this dataset, many of the samples for which multiple minerals were dated yielded highly discordant ages. In examining the data, we noted a spatial pattern in the age distribution. Consistently, the youngest ages are on the west side of the terrane and the ages increase eastward. Within this spatial distribution pattern, the discordance between mineral phases also increases eastward; a number of the samples yielding youngest ages show concordant or only mildly discordant ages (for example, samples DT 76-57 and DT 75-67, table 1), whereas samples yielding older ages show extreme discordance (for example, sample DT 76-70, table 1). If the K-Ar ages are interpreted as cooling ages, then the K-Ar ages indicate late rapid cooling on the west and a more protracted and longer cooling on the east. Alternatively, if multiple thermal disturbances impacted the terrane through time, then these disturbances variably reset the $\mathrm{K}-\mathrm{Ar}$ systems and disturbed the $\mathrm{Rb} / \mathrm{Sr}$ systematics. Complicating any interpretation is that in a number of samples, biotite yielded K-Ar ages significantly older than co-existing hornblende, the reverse of what would be predicted from a simple cooling hypothesis.

Turner and coworkers suggested possible excess argon in the biotite to explain the $2.5 \mathrm{Ga}$ biotite ages. However, excess argon seems unlikely and the hornblende ages might be as much or more questionable than the biotite ages. Layer's analysis (fig. I-1) of one hornblende sample (DT 76-70, table I-1) indicated disturbance in the argon system in the mineral; this was in a sample that had yielded the predictable discordance of biotite younger than hornblende. In this case, the biotite yielded an age substantially younger than the hornblende age, $685 \pm 20 \mathrm{Ma}$ versus $915 \pm 27 \mathrm{Ma}$.

A few of the biotite samples had anomalously low $\mathrm{K}_{2} \mathrm{O}$ contents and as such the ages determined are quite likely suspect. John Obradovich (USGS, oral commun., 1982) indicated that if the biotite $\mathrm{K}_{2} 0$ is less than 6 percent, then the $\mathrm{K}-\mathrm{Ar}$ age is suspect; sample DT 76-34 has only 5.190 percent $\mathrm{K}_{2} \mathrm{O}$ and the percent ${ }^{40} \mathrm{Ar}$ radiogenic is also low. Sample 75AFS-22AK has $\mathrm{K}_{2} \mathrm{O}$ just above 6 percent and replicate splits produced discordant dates.

This is clearly a very complex package of rocks and many dating methods have been employed. Potassium-argon based methods were not adequate to clarify the later history of the terrane. The rubidium-strontium method used by Turner and others used on a suite of samples and used on a similar suite of samples reported by Moll-Stalcup and others (1996), was limited in resolving questions about the history of these rocks although $\mathrm{Rb} / \mathrm{Sr}$ data from both suites, in conjunction with some $\mathrm{K}-\mathrm{Ar},{ }^{40} \mathrm{Ar} /{ }^{39} \mathrm{Ar}$, and $\mathrm{U} / \mathrm{Pb}$ data suggested that an event at about $1.8 \mathrm{Ga}$ affected the terrane. Uranium-lead data on orthogneiss yielded most of the oldest ages for rocks of this complex (Turner and others, this manuscript; Box and others, 1990; 1993; Moll-Stalcup and others, 1996) and consistently indicated an age of about $2.05 \mathrm{Ga}$. Bradley and others (2007) reported a concordant $2.08 \mathrm{Ga}( \pm 10 \mathrm{~m} . \mathrm{y}.) \mathrm{U} / \mathrm{Pb}$ zircon age from an orthogneiss from the Kilbuck terrane.

\section{References Cited in Preface}

Aleinikoff, J.N., Dusel-Bacon, Cynthia, Foster, H.L., and Futa, Kiyoto, 1981, Proterozoic zircon from augen gneiss, Yukon-Tanana Upland, east-central Alaska: Geology, v. 9, p. 469-473.

Aleinikoff, J.N., Dusel-Bacon, Cynthia, and Foster, H.L., 1986, Geochronology of augen gneiss and related rocks, Yukon-Tanana terrane, east-central Alaska: Geological Society of America Bulletin, v. 97, p. 626-637. 
Box, S.E., Moll-Stalcup, E.J., Wooden, J.L., and Bradshaw, J.Y., 1990, Kilbuck terrane-Oldest known rocks in Alaska: Geology, v. 18, p. 1219-1222.

Box, S.E., Moll-Stalcup, E.J., Frost, T.P., and Murphy, J.M., 1993, Preliminary geologic map of the Bethel and southern Russian Mission quadrangles, southwestern Alaska: U.S. Geological Survey Miscellaneous Field Studies Map MF-2226-A, scale 1:250,000.

Bradley, D., Miller, M., McClelland, W., Dumoulin, J., Friedman, R., and O'Sullivan, P., 2007, Links between Alaska's Kilbuck, Farewell, and Arctic Alaska terranes and the Siberian and Laurentian cratons [abs.]: Abstracts and Proceedings of the Geological Society of Norway, NGF Number 2, p. 230.

Hoare, J.M., and Coonrad, W.L., 1959, Geology of the Bethel quadrangle, Alaska: U.S. Geological Survey Miscellaneous Geologic Investigations Map I-285, scale $1: 250,000$.

Hoare, J.M., and Coonrad, W.L., 1961, Geologic map of Goodnews quadrangle, Alaska: U.S. Geological Survey Miscellaneous Geologic Investigations Map I-339, scale 1:250,000. [Goodnews quadrangle subsequently renamed Goodnews Bay quadrangle.]

Hoare, J.M., and Coonrad, W.L., 1978, Geologic map of the Goodnews Bay and Hagemeister Island quadrangles region, southwestern Alaska: U.S. Geological Survey Open-File Report 78-9-B, scale 1:250,000, 2 sheets.

Hoare, J.M., and Coonrad, W.L., 1979, The Kanektok metamorphic complex, a rootless belt of Precambrian rocks in southwestern Alaska, in Johnson, K.M., and Williams, J.R., eds., The United States Geological Survey in AlaskaAccomplishments during 1978: U.S. Geological Survey Circular 804-B, p. 7274.

Jones, D.L., Silberling, N.J., Berg, H.C., and Plafker, George, 1981, Map showing tectonostratigraphic terranes of Alaska, columnar sections, and summary description of terranes: U.S. Geological Survey Open-File Report 81-792, 20 p., 2 sheets, scale 1:2,500,000.

Moll-Stalcup, Elizabeth, Wooden, J.L., Bradshaw, Jack, and Aleinikoff, John, 1996, Elemental and isotopic evidence for $2.1 \mathrm{Ga}$ arc magmatism in the Kilbuck terrane, southwestern Alaska, in Moore, T.E., and Dumoulin, J.A., eds., Geologic studies in Alaska by the U.S. Geological Survey, 1994: U.S. Geological Survey Bulletin 2152, p. 111-130.

Wilson, F.H., Hults, C.P., Mohadjer, Solmaz, Coonrad, W.L., Shew, Nora, and Labay, K.A., 2008, Digital data for the reconnaissance geologic map for the Kuskokwim Bay region of southwest Alaska, including the Bethel, Goodnews Bay, Nushagak Bay, Hagemeister Island, Baird Inlet, Cape Mendenhall, Kuskokwim Bay, Nunivak Island, Saint Matthew, and Pribilof Islands 1:250,000-scale quadrangles: U.S. Geological Survey Open-File Report 2008-1001, 70 p., scale 1:500,000. [accessed Dec. 1, 2009, at http://pubs.usgs.gov/of/2008/1001/]

Wilson, F.H., Smith, J.G., and Shew, N., 1985, Review of radiometric data from the Yukon crystalline terrane, Alaska and Yukon Territory: Canadian Journal of Earth Sciences, v. 22, p. 525-537. 


\section{Geologic and Geochronologic Studies of the Early Proterozoic Kanektok Metamorphic Complex of Southwestern Alaska}

By Donald L. Turner', Robert B. Forbes' ${ }^{1}$, John N. Aleinikoff², Ian McDougall'3, and Carl E. Hedge $^{2}$

\section{Abstract}

The Kanektok complex of southwestern Alaska appears to be a rootless terrane of early Proterozoic sedimentary, volcanic, and intrusive rocks which were metamorphosed to amphibolite and granulite facies and later underwent a pervasive late Mesozoic thermal event accompanied by granitic plutonism and greenschist facies metamorphism of overlying sediments. The terrane is structurally complex and exhibits characteristics generally attributed to mantled gneiss domes.

$\mathrm{U}-\mathrm{Th}-\mathrm{Pb}$ analyses of zircon and sphene from a core zone granitic orthogneiss indicate that the orthogneiss protolith crystallized about 2.05 b.y. ago and that the protolithic sedimentary, volcanic and granitic intrusive rocks of the core zone were metamorphosed to granulite and amphibolite facies about 1.77 b.y. ago. A Rb-Sr study of 13 whole-rock samples also suggests metamorphism of an early Proterozoic [Paleoproterozoic] protolith at $1.77 \mathrm{Ga}$, although the data are scattered and difficult to interpret.

Seventy-seven conventional ${ }^{40} \mathrm{~K} /{ }^{40} \mathrm{Ar}$ mineral ages were determined for 58 rocks distributed throughout the outcrop area of the complex. Analysis of the K-Ar data indicate that nearly all of these ages have been totally or partially reset by a pervasive late Mesozoic thermal event accompanied by granitic plutonism and greenschist facies metamorphism. Several biotites gave apparent K-Ar ages over $2 \mathrm{Ga}$. These ages appear to be controlled by excess radiogenic ${ }^{40} \mathrm{Ar}$ produced by the degassing protolith during the $1.77 \mathrm{Ga}$ metamorphism and incorporated by the biotites when they were at temperatures at which Ar could diffuse through the lattice.

Five amphibolites yielded apparent Precambrian ${ }^{40} \mathrm{~K} /{ }^{40} \mathrm{Ar}$ hornblende ages. There is no evidence that these hornblende ages have been increased by excess argon. The oldest ${ }^{40} \mathrm{~K} /{ }^{40} \mathrm{Ar}$ hornblende age of $1.77 \mathrm{Ga}$ is identical to the sphene ${ }^{207} \mathrm{~Pb} /{ }^{206} \mathrm{~Pb}$ orthogneiss age and to the $\mathrm{Rb}-\mathrm{Sr}$ "isochron" age for six of the 13 whole-rock samples.

The younger hornblende ages are interpreted as having been partially reset during the late Mesozoic thermal event.

${ }^{40} \mathrm{Ar} /{ }^{39} \mathrm{Ar}$ incremental heating experiments suggest metamorphism occurred at least 1.2 b.y. ago but do not exhibit high temperature plateau ages significantly older than the ${ }^{40} \mathrm{Ar} /{ }^{39} \mathrm{Ar}$ total fusion ages of these samples. The age spectra are much more uniform than expected from a terrane with such a complex thermal history, perhaps caused by the small grain size of the samples which may possibly be less than the effective Ar diffusion radii of the analyzed hornblendes.

\footnotetext{
${ }^{1}$ Geophysical Institute, University of Alaska, Fairbanks, Alaska, USA

${ }^{2}$ U.S. Geological Survey, Denver, Colorado, USA

${ }^{3}$ Research School of Earth Sciences, Australian National University, Canberra, ACT, Australia
} 
The Kanektok complex comprises the Kilbuck tectonostratigraphic terrane of Jones and others (1981). The $1.77 \mathrm{Ga}$ age of its high grade metamorphic rocks is significantly older than nearly all radiometric ages previously determined thus far for Alaskan rock units. The age and lithology of this terrane appear to be unique in Alaska. These characteristics should prove useful in tectonic reconstructions aimed at finding the source region for this terrane prior to its migration to its present position in southwestern Alaska.

\section{Introduction}

The search for documented Precambrian crystalline rocks in Alaska has proven to be unexpectedly long and complex. Spurr (1898) first assigned a Precambrian age to metamorphic rocks formerly known as the Birch Creek Schist in the Yukon-Tanana Upland. For many years thereafter, newly discovered metamorphic terranes in northern Alaska were arbitrarily correlated with the Birch Creek Schist and assigned a Precambrian age. Subsequently, however, the application of radiometric dating techniques has failed to document a Precambrian age for the metamorphic rocks of the Yukon-Tanana Upland. Aleinikoff and others (1981) have shown (by the U-Th-Pb zircon method) that a 350 m.y. old augen gneiss was derived from an early Proterozoic (about 2.3 b.y. old) parent rock. More recent studies (Aleinikoff and others, 1984) reveal that many metasedimentary rocks located throughout the Yukon-Tanana Upland, including wall rocks to the aforementioned augen gneiss, contain detrital zircons approximately 2.0 and 2.3 b.y. old.

Although many radiometric ages have been determined for various Alaskan metamorphic terranes, reliable Precambrian radiometric ages have been published for only three areas to date; a $\mathrm{Rb}-\mathrm{Sr}$ whole-rock isochron age of $735 \mathrm{Ma}$ determined for gneiss from the Kigluaik Mountains of the Seward Peninsula (Bunker and others, 1977); 587-756 Ma K-Ar mineral ages from a blueschist terrane in the southwestern Brooks Range (Turner and others, 1979, Mayfield and others, 1982); and a $730 \mathrm{Ma}{ }^{207} \mathrm{~Pb} /{ }^{206} \mathrm{~Pb}$ zircon age from a trondhjemite pluton cutting amphibolite of the Wales Group in southeastern Alaska (Churkin and Eberlein, 1977). In addition, Aleinikoff and others (1986) determined an approximately $2 \mathrm{Ga}{ }^{207} \mathrm{~Pb} /{ }^{206} \mathrm{~Pb}$ zircon age for a metarhyodacite in the eastern Alaska Range.

Precambrian sedimentary rocks have been delineated by paleontologic evidence at very few localities in northeastern Alaska. The Tindir Group of later Precambrian age (Subdivision Y = 800-1,600 Ma [early Neoproterozoic and Mesoproterozoic]), is exposed in two relatively small areas north of the Yukon River (Mertie, 1937; Brabb and Churkin, 1969); and Precambrian greenschist facies metasedimentary rocks unconformably underlie Olenellus-bearing sediments of the Neruokpuk Formation in the eastern Brooks Range (Dutro and others, 1972). The Precambrian localities discussed above are shown in figure 1.

The Kanektok metamorphic complex of southwestern Alaska was dated by several radiometric methods in order to determine the age of its protolith and the ages of subsequent metamorphic events. 


\section{Geology}

\section{Regional Geology and Tectonic Setting}

Rocks of the Kanektok complex are exposed along a relatively narrow, northeast trending belt, which extends $160 \mathrm{~km}$ from the highlands east of Kuskokwim Bay across the northwest corner of the Goodnews quadrangle into the Bethel quadrangle (fig. 2). These rocks were first mapped and described by Hoare and Coonrad $(1959,1961)$ as a metamorphic complex composed of highly metamorphosed sedimentary and volcanic rocks, which probably included some recrystallized intrusive rocks. The complex was originally mapped as Precambrian because the rocks are more metamorphosed than nearby strata of Paleozoic age. As summarized in Hoare and Coonrad's earlier descriptions, the complex is dominated by pink and grey gneisses and light- to dark-grey schist, with subordinate marble, quartz-muscovite schist and amphibolite.

The complex is bordered on the southeast by a broad belt of isoclinally folded rocks ranging in age from Devonian to late Early Cretaceous (Albian) age. Folds in this belt verge northwestward, and are overturned or recumbent. The fold style suggests the existence of low-angle thrust faults.

North of the Kanektok River, the complex is bordered on the northwest by a narrow belt of sedimentary rocks of Late Cretaceous age, and by a wide, poorly exposed belt of andesitic volcanic rocks of Middle Jurassic age. The intensity and style of deformation in the volcanic rocks is unknown, due to lack of outcrop, but the sedimentary rocks of Late Cretaceous age are much less deformed than the Albian rocks on the southeast side of the complex.

Glacial deposits border the metamorphic complex south of the Kanektok River. Aeromagnetic data suggest that these glacial deposits are underlain by volcanic rocks. The magnetic anomaly pattern indicates that the volcanics dip southward toward the metamorphic complex, suggesting a possible fault contact.

In late Early Cretaceous (Albian) time, the northeastern part of the metamorphic complex was emergent and subject to erosion. A thick wedge of sedimentary rocks was deposited east and southeast of the complex. Conglomerate in this unit contains gneiss and schist clasts derived from the complex, whereas finer grained sediments contain abundant detrital muscovite. The north end of the metamorphic complex is chiefly concealed beneath a thin veneer of these sediments which thicken rapidly to the east and southeast. 


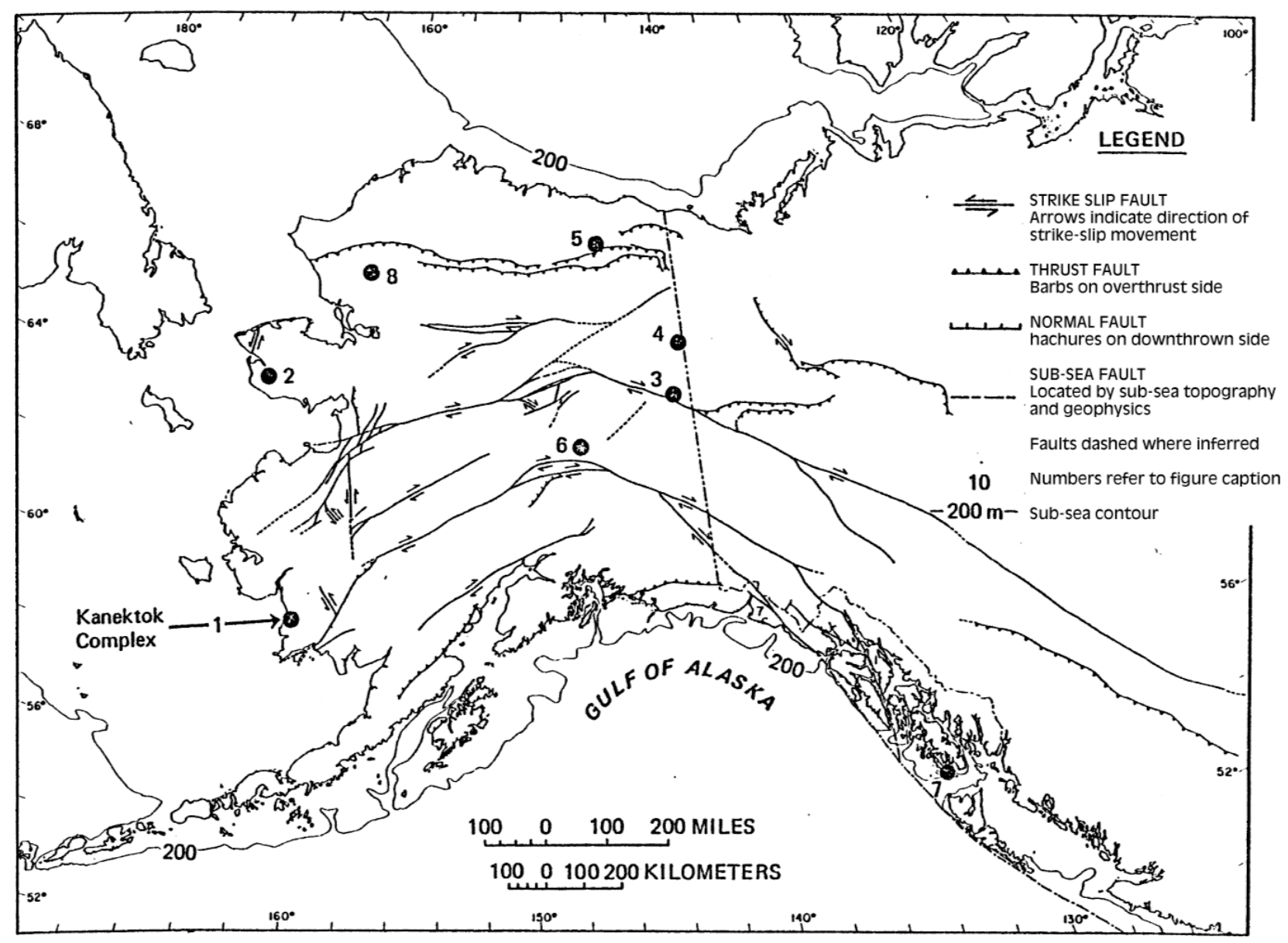

Figure 1. Tectonic map of Alaska and adjacent areas in Canada, showing 8 localities of Precambrian rocks discussed in this report: 1. Kanektok Complex.

2. The Kigluaik Mountains; site of the $735 \mathrm{Ma} \mathrm{Rb-Sr}$ whole rock isochron age reported by Bunker and others (1977).

3. Precambrian Tindir Group locality; Circle District.

4. Precambrian Tindir Group locality; Porcupine District

5. Neruokpuk Formation; Olenellus locality.

6. Metarhyodacite in eastern Alaska Range yielding an approximately 2 b.y. ${ }^{207} \mathrm{~Pb} /{ }^{206} \mathrm{~Pb}$ zircon age (Aleinikoff and others, 1986).

7. Prince of Wales Island, where a trondhjemite pluton dated at $730 \mathrm{Ma}$ intrudes amphibolite of the Wales Group (Churkin and Eberlein, 1977).

8. Precambrian blueschist terrane in southwestern Brooks Range (Turner and others, 1979; Mayfield and others, 1982). 


\section{Structure}

In 1975, Forbes and Turner completed three mapping and sampling traverses across the southwestern part of the Kanektok complex. Turner completed additional mapping and sampling in the northeastern part of the complex in 1976. The best geologic section was obtained from the Thumb Mountain traverse (fig. 3); however, all of the sections are complicated by faulting, and we are unsure as to whether the composite structure section of figure 4 represents a complete section across the complex. For example, the northwest end of the Thumb Mountain and Snow Gulch traverses terminate in coarse-grained dioritic gneisses, whereas the rocks encountered in the northwesternmost traverse include greenschists, marbles and calc-phyllites (fig. 3). However, a reasonable structural picture emerges from a model which assumes that the greenschist facies rocks on the northwest end of this traverse represent the northwest flank of the complex, with similar rocks at the southeast end of the Thumb Mountain traverse as the southeast flank of the complex. The resultant composite section is shown in figure 4.

The Kanektok terrane appears to be an antiformal crystalline complex cored by granitic gneisses with intercalated metabasites and metasediments, flanked by an outer zone or envelope of greenschist facies rocks. Rocks in the outer zone dip away from the complex, and the core zone granitic gneisses appear to be deformed into sub-isoclinal upright folds with limbs which descend toward the margins of the complex. Mineral foliation tends to parallel compositional layering, and the mineral lineation, foliation and layering strike consistently to the northeast (fig. 3).

\section{Petrology}

The central zone of the complex is dominated by layered biotite- hornblende gneisses with intercalated pyroxene granulites, garnet amphibolites, garnet-mica schists, orthogneisses and rare marbles and quartzites. The biotite-hornblende gneisses range in composition from diorite to granodiorite. The orthogneisses are granitic to monzonitic, coarse grained, and characterized by pink orthoclase.

The pyroxene granulites represent lower granulite facies metamorphic rocks with the assemblage garnet-augite-biotite and anti-perthitic plagioclase. K-feldspar bearing variants are also present. Pyroxene granulites thus far located are restricted to the Snow Gulch traverse, on both sides of the Snow Gulch Fault (fig. 3). Layered biotitehornblende gneisses, which dominate the central segment of the Thumb Mountain traverse, typically have granodioritic or quartz dioritic whole rock compositions. Biotite ( \pm muscovite) orthogneiss masses, with compositions ranging from granite to quartz monzonite and monzonite (fig. 3), are in part discordant to the layering and foliation in adjacent rock units. These units typically contain pink K-feldspar, and a fabric dominated by flaser or augen structure.

Pelitic schists and marbles are rare in the core of the complex. However, a kyanite-bearing garnet-mica schist was collected from one station on the southeastern segment of the Thumb Mountain traverse, and an impure marble with incipient diopside was recovered from a nearby outcrop. The kyanite and diopside "in" reactions are in agreement with the first appearance of garnet amphibolites in the same part of the section. Intercalated marble units are thin and discontinuous, and often contain white mica, phlogopite, quartz, plagioclase and epidote as minor phases.

The northwest and southeast margins of the complex are bounded by greenschist facies rocks which appear to grade into the amphibolite facies rocks of the core zone. 
The greenschist facies rocks include greenschists, epidote-quartz-biotite schists, micaceous quartzites, calc-phyllites, marbles, feldspathic quartzites, and metaconglomerates.

On the northwest flank of the complex, the marginal facies rocks disappear under valley floor alluvial deposits. On the southeast margin near Keno Creek the greenschist facies rocks appear to be in fault contact with Cretaceous sediments.
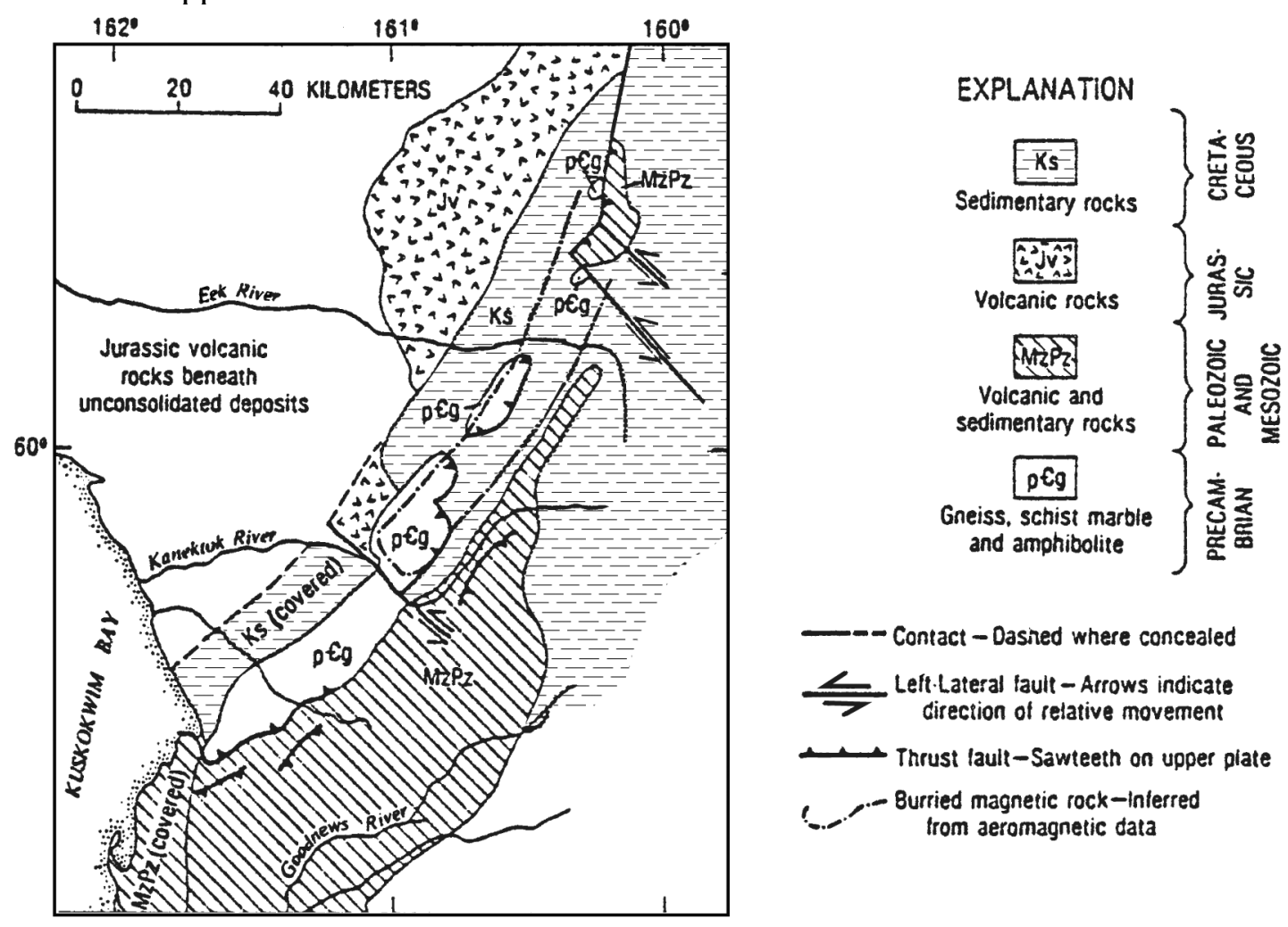

Figure 2. Geologic map of the Kanektok complex and associated rocks (from Hoare and Coonrad, 1979).

\section{Suggested Structural Model}

The structural and petrologic characteristics of the Kanektok complex appear to be similar to those described elsewhere for "mantled gneiss domes", including a core zone of older metamorphic rocks overlain by an envelope of younger greenschist or epidote-amphibolite facies (supracrustal) metasediments. According to more recent models, such domes may be formed by upfaulted piston or trapdoor-like basement blocks of older crust, accompanied by the emplacement of synkinematic and post-kinematic granitic rocks. ${ }^{1}$ The accompanying thermal perturbation is responsible for recrystallizing the overlying supracrustal sediments under the pressue/temperature conditions of the greenschist and/or epidote-amphibolite facies. Removal of supracrustal rocks by subsequent erosion during the final stage of uplift of the complex exposes the older and higher grade metamorphic core, surrounded by an envelope of greenschist facies rocks.

\footnotetext{
${ }^{1}$ Many gneiss domes are now thought to be extensional core complexes.
} 


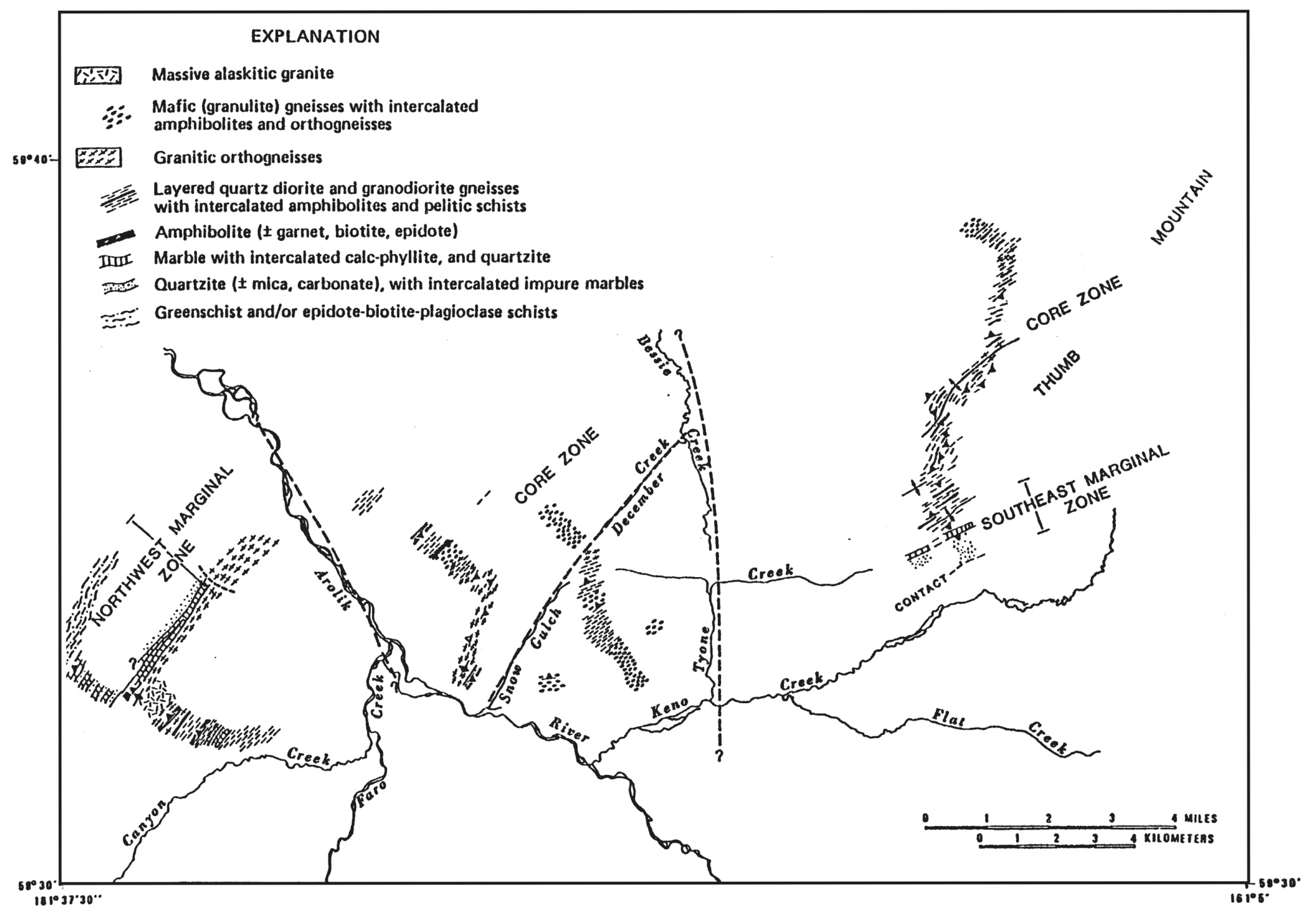

Figure 3. Geologic traverse map of the southwestern part of the Kanektok complex based on field work by Forbes and Turner in 1975. 

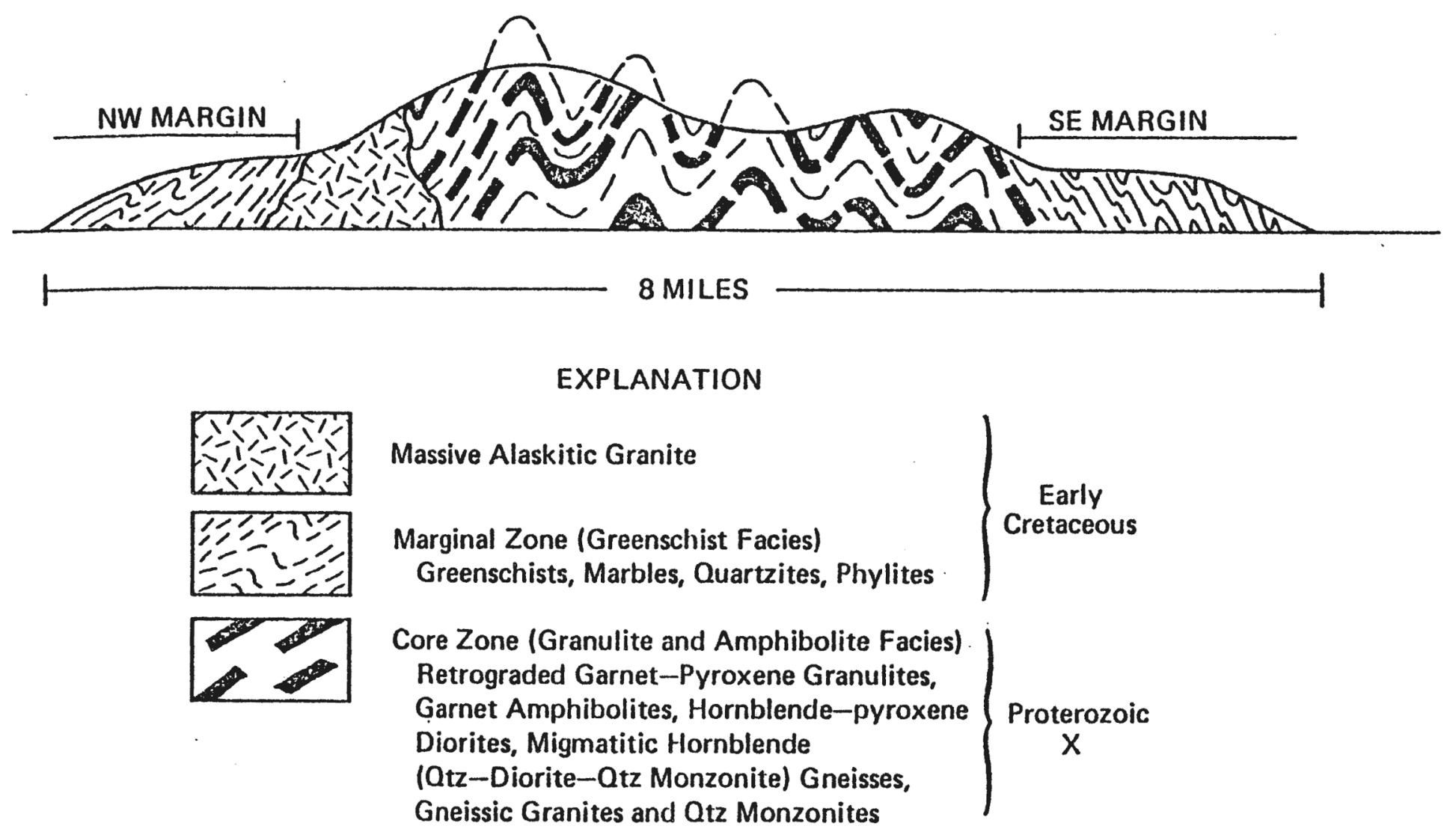

Figure 4. Diagrammatic structure section across Kanektok complex. 
Although mapping of the Kanektok complex provides a reasonable fit for the proposed model, the stratigraphy of the layered metamorphic rocks has been disrupted by both high angle vertical and low angle thrust faulting. Block faulting and imbrication within the complex have resulted in a complex outcrop pattern within the core zone.

Hoare and Coonrad (1979) have reported field mapping, gravity and aeromagnetic data indicating that the Kanektok complex is rootless and thrust over underlying Paleozoic and Mesozoic sedimentary and volcanic rocks, as shown in figure 2. The apparent 2-sided symmetry and descending antiformal structural style of the complex does not fit the asymmetrical structural style and zonation pattern that one expects to encounter in "rootless" crystalline thrust plates. However, the evidence presented by Hoare and Coonrad (1979) for an allochthonous origin of the complex is convincing, and it is difficult to offer a satisfactory explanation for an apparent allochthonous origin versus structural and petrologic characteristics that are generally attributed to mantled gneiss domes. Jones and others (1981) accepted the evidence of Hoare and Coonrad (1979) that the complex is rootless, re-named it the Kilbuck terrane, and designated it as one of the 50 tectonostratigraphic terranes which they have defined in Alaska. ${ }^{2}$

\section{Geochronology}

\section{${ }^{40} \mathrm{~K} /{ }^{40} \mathrm{Ar}$ Studies}

Thus far, $77{ }^{40} \mathrm{~K} /{ }^{40}$ Ar total fusion mineral ages have been determined for 58 rocks distributed throughout the major outcrop areas of the Kanektok complex. Mineral separations and K-Ar analyses were done by D.L. Turner at the Geochronology Laboratory of the Geophysical Institute, University of Alaska, Fairbanks. Analytical data are given in table 1.

Figure 5 is a histogram of these ages which range from 120 to 2,500 Ma. Seventy-three percent are grouped in the 120-225 Ma range and most of these are in the 120-150 Ma range (latest Jurassic to earliest Cretaceous). Ages in the 120-150 Ma range from both biotite and hornblende are present in all rock types throughout the entire length of the complex. These younger ages are interpreted as having been reset by a pervasive late Mesozoic thermal event accompanied by plutonism. An unfoliated alaskitic granite body intrudes greenschists in the southwestern part of the complex (figs. 3 and 4). The granite contains no biotite or hornblende and therefore could not be dated by K-Ar methods. Greenschists near the granite contact, however, gave an actinolite age of 137 $\mathrm{Ma}$ and a biotite age of $130 \mathrm{Ma}$. An amphibolite 2 miles north of the contact gave a hornblende age of $146 \mathrm{Ma}$. No older apparent ages were found within 4 miles of the contact. The widespread distribution of 120-150 Ma ages and the occurrence of small scale igneous intrusive bodies throughout the complex (table 1) indicate that the entire complex was affected by the late Mesozoic thermal event. The numerous biotite, muscovite and hornblende K-Ar ages older than 100-150 Ma and younger than $1.77 \mathrm{Ga}$ (fig. 5) are believed to represent Precambrian rocks that have undergone varying degrees of partial argon loss during the late Mesozoic thermal event.

\footnotetext{
${ }^{2}$ At present, few workers believe 50 tectonically independent terranes exist in Alaska as the definitions of many of these terranes have been revised or abandoned.
} 
Table 1. Analytical data for K-Ar analyses of samples from Kanektok complex.

[Sample collectors: AHR, J.M. Hoare; AFS, R.B. Forbes; DT, D.L. Turner, $\mathrm{x}=$ number of analyses for $\mathrm{K}_{2} \mathrm{O}$ ]

\begin{tabular}{|c|c|c|c|c|c|c|c|c|c|c|c|}
\hline Sample No. & $\begin{array}{l}\text { Lab } \\
\text { No. }\end{array}$ & $\underset{{ }^{\circ} \mathbf{N}}{\text { Latitude }}$ & $\begin{array}{c}\text { Longitude } \\
{ }^{\circ} \mathbf{W}\end{array}$ & Rock Type & Mineral & $\mathbf{x}$ & $\begin{array}{c}\mathbf{K}_{2} \mathbf{O} \\
(\mathbf{w t .} \%)\end{array}$ & $\begin{array}{c}{ }^{40} \mathrm{Ar}_{\mathrm{rad}} \\
(\mathrm{mol} / \mathrm{g}) \mathrm{x} \\
\mathbf{1 0}^{-11}\end{array}$ & $\begin{array}{l}{ }^{40} \mathrm{Ar} \mathbf{r}_{\text {rad }} / \\
{ }^{40} \mathrm{~A} \mathbf{r}_{\text {total }}\end{array}$ & $\begin{array}{l}\text { Age } \\
\text { (Ma) }\end{array}$ & $\begin{array}{c} \pm 1 \\
(\mathrm{~m} . \mathrm{y} .)\end{array}$ \\
\hline 50AHR747A & 72003 & 59.7250 & 161.1083 & quartz diorite & biotite & 1 & 7.840 & 561.70 & 0.937 & 439.5 & 12.9 \\
\hline 50AHR747A & 72003 & 59.7250 & 161.1083 & quartz diorite & biotite & 2 & 7.840 & 561.70 & 0.937 & 439.5 & 13.0 \\
\hline 50AHR747A & 72151 & 59.7250 & 161.1083 & quartz diorite & hornblende & 4 & 1.417 & 128.40 & 0.964 & 539.9 & 15.9 \\
\hline 50AHR747A & 72147 & 59.7250 & 161.1083 & quartz diorite & hornblende & 2 & 1.417 & 129.60 & 0.820 & 544.3 & 16.0 \\
\hline 50AHR747A & 72147 & 59.7250 & 161.1083 & quartz diorite & hornblende & 4 & 1.417 & 129.60 & 0.820 & 544.3 & 16.1 \\
\hline 75 AFS-12K & 76120 & 59.5767 & 161.2350 & garnet amphibolite & muscovite & 4 & 10.051 & 205.20 & 0.883 & 136.5 & 3.9 \\
\hline $75 \mathrm{AFS}-12 \mathrm{~K}$ & 76127 & 59.5767 & 161.2350 & garnet amphibolite & hornblende & 4 & 0.801 & 19.69 & 0.777 & 163.1 & 4.8 \\
\hline 75AFS-18AK & 76123 & 59.6167 & 161.3883 & $\begin{array}{l}\text { biotite muscovite } \\
\text { granodiorite gneiss }\end{array}$ & muscovite & 2 & 10.595 & 214.70 & 0.842 & 135.5 & 3.9 \\
\hline 75AFS-18AK & 76128 & 59.6167 & 161.2050 & $\begin{array}{l}\text { biotite muscovite } \\
\text { granodiorite gneiss }\end{array}$ & biotite & 2 & 8.916 & 191.90 & 0.970 & 143.6 & 4.2 \\
\hline 75AFS-18CK & 76122 & 59.6200 & 161.2000 & $\begin{array}{c}\text { biotite-bearing } \\
\text { amphibolite }\end{array}$ & hornblende & 4 & 1.090 & 21.76 & 0.846 & 133.6 & 3.9 \\
\hline 75AFS-1K & 76131 & 59.6117 & 161.2283 & $\begin{array}{c}\text { biotite-muscovite } \\
\text { gneiss }\end{array}$ & biotite & 2 & 9.220 & 236.10 & 0.969 & 169.6 & 4.9 \\
\hline 75AFS-22AK & 76121 & 59.6450 & 161.2050 & $\begin{array}{l}\text { biotite-hornblende } \\
\text { diorite gneiss }\end{array}$ & biotite & 2 & 6.480 & 166.60 & 0.961 & 170.3 & 4.9 \\
\hline 75AFS-22AK & 76172 & 59.6450 & 161.2050 & $\begin{array}{c}\text { biotite-hornblende } \\
\text { diorite gneiss }\end{array}$ & biotite & 2 & 6.480 & 194.80 & 0.956 & 197.6 & 19.3 \\
\hline 75AFS-22AK & 76172 & 59.6450 & 161.2050 & $\begin{array}{l}\text { biotite-hornblende } \\
\text { diorite gneiss }\end{array}$ & biotite & 2 & 6.480 & 194.80 & 0.956 & 197.6 & 5.8 \\
\hline 75AFS-22AK & 76119 & 59.6450 & 161.2050 & $\begin{array}{l}\text { biotite-hornblende } \\
\text { diorite gneiss }\end{array}$ & hornblende & 4 & 1.160 & 43.88 & 0.946 & 245.3 & 7.2 \\
\hline
\end{tabular}


Table 1. Analytical data for K-Ar analyses of samples from Kanektok complex (cont.).

\begin{tabular}{|c|c|c|c|c|c|c|c|c|c|c|c|}
\hline Sample No. & $\begin{array}{l}\text { Lab } \\
\text { No. }\end{array}$ & $\underset{{ }^{\circ} \mathbf{N}}{\text { Latitude }}$ & $\begin{array}{c}\text { Longitude } \\
{ }^{\circ} \mathrm{W}\end{array}$ & Rock Type & Mineral & $\mathbf{x}$ & $\begin{array}{c}\mathbf{K}_{2} \mathbf{O} \\
(\mathbf{w t .} \%)\end{array}$ & $\begin{array}{c}{ }^{40} \mathrm{Ar}_{\mathrm{rad}} \\
(\mathrm{mol} / \mathrm{g}) \mathrm{x} \\
\mathbf{1 0}^{-11}\end{array}$ & ${ }^{40} \mathrm{~A} \mathbf{r}_{\text {rad }} /$ & $\begin{array}{l}\text { Age } \\
\text { (Ma) }\end{array}$ & $\begin{array}{c} \pm 1 \\
(\mathrm{~m} . \mathrm{y} .)\end{array}$ \\
\hline 75AFS-23AK & 77107 & 59.6500 & 161.2067 & $\begin{array}{l}\text { biotite-hornblende } \\
\text { diorite gneiss }\end{array}$ & biotite & 2 & 8.426 & 255.80 & 0.941 & 199.4 & 5.8 \\
\hline 75AFS-28AK & 77103 & 59.5700 & 161.4417 & $\begin{array}{l}\text { biotite-hornblende } \\
\text { biotite gneiss }\end{array}$ & hornblende & 2 & 1.344 & 38.02 & 0.963 & 186.5 & 5.5 \\
\hline 75AFS-35AK & 77164 & 59.5817 & 161.3967 & $\begin{array}{l}\text { biotite-hornblende } \\
\text { granodiorite }\end{array}$ & biotite & 2 & 8.702 & 180.70 & 0.891 & 138.8 & 4.1 \\
\hline 75AFS-35AK & 77071 & 59.5817 & 161.3967 & $\begin{array}{l}\text { biotite-hornblende } \\
\text { granodiorite }\end{array}$ & hornblende & 4 & 0.785 & 28.41 & 0.876 & 235.3 & 6.9 \\
\hline 75AFS-3K & 76126 & 59.6067 & 161.2250 & $\begin{array}{c}\text { epidote } \\
\text { amphibolite }\end{array}$ & $\begin{array}{c}\text { biotite } \\
\text { (impure) }\end{array}$ & 3 & 7.391 & 162.20 & 0.956 & 146.3 & 4.3 \\
\hline 75AFS-3K & 76124 & 59.6067 & 161.2250 & $\begin{array}{c}\text { epidote } \\
\text { amphibolite }\end{array}$ & hornblende & 4 & 1.110 & 28.56 & 0.894 & 170.4 & 4.9 \\
\hline DT 75-60 & 76057 & 59.5433 & 161.4617 & garnet amphibolite & hornblende & 2 & 0.805 & 20.61 & 0.879 & 169.6 & 5.0 \\
\hline DT 75-61 & 76081 & 59.5433 & 161.4583 & $\begin{array}{c}\text { retrograded } \\
\text { pyroxene granulite }\end{array}$ & biotite & 2 & 9.101 & 5778.00 & 0.998 & 2231.1 & 67 \\
\hline DT 75-61 & 76159 & 59.5433 & 161.4583 & $\begin{array}{c}\text { retrograded } \\
\text { pyroxene granulite }\end{array}$ & biotite & 2 & 9.101 & 6147.00 & 0.994 & 2311.1 & 70 \\
\hline DT 75-61 & 76159 & 59.5433 & 161.4583 & $\begin{array}{c}\text { retrograded } \\
\text { pyroxene granulite }\end{array}$ & biotite & 2 & 9.101 & 6147.00 & 0.994 & 2311.1 & 70 \\
\hline DT 75-62 & 76052 & 59.5783 & 161.4550 & garnet amphibolite & hornblende & 4 & 0.630 & 24.09 & 0.822 & 247.8 & 7.2 \\
\hline DT 75-63 & 76082 & 59.5767 & 161.4500 & $\begin{array}{c}\text { biotite-granodiorite } \\
\text { gneiss }\end{array}$ & biotite & 2 & 8.946 & 177.80 & 0.961 & 133.0 & 3.9 \\
\hline DT 75-64 & 76063 & 59.5717 & 161.4417 & $\begin{array}{l}\text { biotite-hornblende- } \\
\text { granodiorite gneiss }\end{array}$ & biotite & 2 & 8.567 & 167.20 & 0.933 & 130.7 & 3.8 \\
\hline DT 75-64 & 76070 & 59.5717 & 161.4417 & $\begin{array}{l}\text { biotite-hornblende- } \\
\text { granodiorite gneiss }\end{array}$ & hornblende & 2 & 0.770 & 16.33 & 0.714 & 141.6 & 4.1 \\
\hline
\end{tabular}


Table 1. Analytical data for K-Ar analyses of samples from Kanektok complex (cont.).

\begin{tabular}{|c|c|c|c|c|c|c|c|c|c|c|c|}
\hline Sample No. & $\begin{array}{l}\text { Lab } \\
\text { No. }\end{array}$ & $\begin{array}{l}\text { Latitude } \\
{ }^{\circ} \mathbf{N}\end{array}$ & $\begin{array}{l}\text { Longitude } \\
{ }^{\circ} \mathrm{W}\end{array}$ & Rock Type & Mineral & $\mathbf{x}$ & $\begin{array}{c}\mathrm{K}_{2} \mathrm{O} \\
(\mathrm{wt} . \%)\end{array}$ & $\begin{array}{c}{ }^{40} \mathrm{Ar}_{\mathrm{rad}} \\
(\mathrm{mol} / \mathrm{g}) \mathrm{x} \\
10^{-11}\end{array}$ & ${ }^{40} \mathbf{A} \mathbf{r}_{\text {rad }} /$ & $\begin{array}{l}\text { Age } \\
\text { (Ma) }\end{array}$ & $\begin{array}{c} \pm 1 \\
(\mathrm{~m} . \mathrm{y} .)\end{array}$ \\
\hline DT 75-66 & 76069 & 59.5617 & 161.4317 & $\begin{array}{l}\text { biotite-hornblende } \\
\text { granodiorite gneiss }\end{array}$ & biotite & 2 & 8.295 & 159.40 & 0.816 & 128.8 & 3.8 \\
\hline DT 75-66 & 76053 & 59.5617 & 161.4317 & $\begin{array}{l}\text { biotite-hornblende } \\
\text { granodiorite gneiss }\end{array}$ & hornblende & 2 & 0.770 & 16.20 & 0.770 & 140.5 & 4.1 \\
\hline DT 75-67 & 76084 & 59.5500 & 161.4400 & $\begin{array}{l}\text { biotite-muscovite } \\
\text { granodiorite gneiss }\end{array}$ & hornblende & 2 & 9.114 & 174.00 & 0.927 & 128.0 & 3.7 \\
\hline DT 75-67 & 76075 & 59.5500 & 161.4400 & $\begin{array}{l}\text { biotite-muscovite } \\
\text { granodiorite gneiss }\end{array}$ & muscovite & 3 & 10.363 & 210.40 & 0.779 & 135.8 & 4.0 \\
\hline DT 75-68 & 76054 & 59.5467 & 161.4367 & $\begin{array}{c}\text { biotite, garnet } \\
\text { amphibolite }\end{array}$ & hornblende & 4 & 0.868 & 18.74 & 0.878 & 144.1 & 4.2 \\
\hline DT 75-69 & 76059 & 59.5633 & 161.3800 & garnet amphibolite & hornblende & 4 & 0.798 & 61.08 & 0.908 & 465.9 & 13.7 \\
\hline DT $75-70$ & 76083 & 59.5583 & 161.3800 & $\begin{array}{c}\text { biotite quartz } \\
\text { monzonite gneiss }\end{array}$ & biotite & 2 & 9.221 & 761.00 & 0.980 & 497.8 & 14.7 \\
\hline DT 75-71 & 76060 & 59.5550 & 161.3717 & pyroxene granulite & biotite & 3 & 9.123 & 4501.00 & 0.995 & 1920.5 & 58 \\
\hline DT 75-71 & 76060 & 59.5550 & 161.3717 & pyroxene granulite & biotite & 3 & 9.123 & 5468.00 & 0.997 & 2158.1 & 65 \\
\hline DT 75-71 & 76168 & 59.5550 & 161.3717 & pyroxene granulite & biotite & 4 & 9.123 & 6663.50 & 0.993 & 2414.2 & 271 \\
\hline DT 75-71 & 76168 & 59.5550 & 161.3717 & pyroxene granulite & biotite & 3 & 9.123 & 6663.50 & 0.993 & 2414.2 & 73 \\
\hline DT 75-71 & 76085 & 59.5550 & 161.3717 & pyroxene granulite & biotite & 3 & 9.123 & 7265.00 & 0.998 & 2530.5 & 76 \\
\hline DT 75-72 & 76061 & 59.5600 & 161.3550 & pyroxene granulite & biotite & 2 & 8.645 & 6397.00 & 0.996 & 2431.5 & 73 \\
\hline DT 75-72 & 76061 & 59.5600 & 161.3550 & pyroxene granulite & biotite & 2 & 8.645 & 6407.00 & 0.975 & 2433.6 & 73 \\
\hline DT 75-72 & 76061 & 59.5600 & 161.3550 & pyroxene granulite & biotite & 2 & 8.645 & 6441.00 & 0.996 & 2440.7 & 74 \\
\hline DT 75-72 & 76163 & 59.5600 & 161.3550 & pyroxene granulite & biotite & 5 & 8.645 & 6976.00 & 0.995 & 2548.5 & 75 \\
\hline DT 75-72 & 76163 & 59.5600 & 161.3550 & pyroxene granulite & biotite & 2 & 8.645 & 6976.00 & 0.995 & 2548.5 & 77 \\
\hline DT 75-72 & 76086 & 59.5600 & 161.3550 & pyroxene granulite & biotite & 2 & 8.645 & 7053.00 & 0.996 & 2563.5 & 77 \\
\hline
\end{tabular}


Table 1. Analytical data for K-Ar analyses of samples from Kanektok complex (cont.).

\begin{tabular}{|c|c|c|c|c|c|c|c|c|c|c|c|}
\hline Sample No. & $\begin{array}{l}\text { Lab } \\
\text { No. }\end{array}$ & $\underset{{ }^{\circ} \mathbf{N}}{\text { Latitude }}$ & $\begin{array}{c}\text { Longitude } \\
{ }^{\circ} \mathbf{W}\end{array}$ & Rock Type & Mineral & $\mathbf{x}$ & $\begin{array}{c}\mathrm{K}_{2} \mathrm{O} \\
(\mathbf{w t .} \%)\end{array}$ & $\begin{array}{c}{ }^{40} \mathrm{Ar}_{\mathrm{rad}} \\
(\mathrm{mol} / \mathrm{g}) \mathrm{x} \\
\mathbf{1 0}^{-11}\end{array}$ & $\begin{array}{l}{ }^{40} \mathrm{Ar}_{\text {rad }} / \\
{ }^{40} \mathrm{Ar}_{\text {total }}\end{array}$ & $\begin{array}{l}\text { Age } \\
\text { (Ma) }\end{array}$ & $\begin{array}{c} \pm 1 \\
(\mathrm{~m} \cdot \mathrm{y} \cdot)\end{array}$ \\
\hline DT 75-73 & 76078 & 59.5633 & 161.3817 & $\begin{array}{c}\text { biotite-muscovite } \\
\text { gneiss }\end{array}$ & muscovite & 2 & 10.095 & 232.30 & 0.836 & 153.1 & 4.5 \\
\hline DT 75-73 & 76089 & 59.5633 & 161.3817 & $\begin{array}{c}\text { biotite-muscovite } \\
\text { gneiss }\end{array}$ & biotite & 2 & 9.227 & 275.10 & 0.974 & 196.0 & 5.7 \\
\hline DT 75-74 & 76044 & 59.5667 & 161.3850 & garnet amphibolite & hornblende & 4 & 0.980 & 37.35 & 0.887 & 247.0 & 7.2 \\
\hline DT 75-76 & 76055 & 59.5467 & 161.4033 & garnet amphibolite & hornblende & 3 & 1.020 & 205.60 & 0.978 & 1036.2 & 31 \\
\hline DT 75-76 & 76160 & 59.5467 & 161.4033 & garnet amphibolite & hornblende & 2 & 1.020 & 212.70 & 0.976 & 1063.3 & 32 \\
\hline DT $75-76$ & 76160 & 59.5467 & 161.4033 & garnet amphibolite & hornblende & 3 & 1.020 & 212.70 & 0.976 & 1063.3 & 32 \\
\hline DT 75-78 & 76080 & 59.5417 & 161.5883 & greenschist & actinolite & 8 & 0.344 & 7.05 & 0.708 & 137.0 & 4.0 \\
\hline DT 75-79 & 76079 & 59.5433 & 161.5933 & $\begin{array}{c}\text { biotite-epidote } \\
\text { schist }\end{array}$ & biotite & 2 & 8.877 & 172.70 & 0.956 & 130.3 & 3.8 \\
\hline DT 75-81 & 76072 & 59.5750 & 161.6017 & $\begin{array}{c}\text { biotite-bearing } \\
\text { greenschist }\end{array}$ & actinolite & 4 & 0.500 & 10.99 & 0.706 & 146.6 & 4.3 \\
\hline DT 75-82 & 77108 & 59.6500 & 161.2117 & $\begin{array}{l}\text { biotite-hornblende- } \\
\text { diorite gneiss }\end{array}$ & biotite & 4 & 8.578 & 278.60 & 0.958 & 212.6 & 6.2 \\
\hline DT 75-82 & 77162 & 59.6500 & 161.2117 & $\begin{array}{l}\text { biotite-hornblende- } \\
\text { diorite gneiss }\end{array}$ & biotite & 2 & 8.578 & 283.00 & 0.970 & 215.7 & 6.3 \\
\hline DT 75-82 & 77162 & 59.6500 & 161.2117 & $\begin{array}{l}\text { biotite-hornblende- } \\
\text { diorite gneiss }\end{array}$ & biotite & 4 & 8.578 & 283.00 & 0.970 & 215.7 & 6.3 \\
\hline DT 75-82 & 77091 & 59.6500 & 161.2117 & $\begin{array}{c}\text { biotite-hornblende- } \\
\text { diorite gneiss }\end{array}$ & hornblende & 4 & 1.214 & 40.33 & 0.933 & 217.1 & 6.4 \\
\hline DT 76-21 & 77109 & 59.9200 & 160.9317 & hornblende diorite & hornblende & 2 & 0.585 & 10.65 & 0.807 & 122.2 & 3.6 \\
\hline DT 76-22 & 77076 & 59.9033 & 160.9200 & garnet amphibolite & hornblende & 4 & 0.824 & 16.07 & 0.810 & 130.6 & 3.8 \\
\hline DT 76-31 & 77089 & 59.9217 & 160.9017 & $\begin{array}{l}\text { biotite-muscovite } \\
\text { gneiss }\end{array}$ & muscovite & 4 & 9.313 & 181.60 & 0.905 & 130.6 & 3.8 \\
\hline
\end{tabular}


Table 1. Analytical data for K-Ar analyses of samples from Kanektok complex (cont.).

\begin{tabular}{|c|c|c|c|c|c|c|c|c|c|c|c|}
\hline Sample No. & $\begin{array}{l}\text { Lab } \\
\text { No. }\end{array}$ & $\underset{{ }^{\circ} \mathbf{N}}{\text { Latitude }}$ & $\begin{array}{c}\text { Longitude } \\
{ }^{\circ} \mathbf{W}\end{array}$ & Rock Type & Mineral & $\mathbf{x}$ & $\begin{array}{c}\mathrm{K}_{2} \mathbf{O} \\
(\mathbf{w t .} \%)\end{array}$ & $\begin{array}{c}{ }^{40} \mathrm{Ar}_{\mathrm{rad}} \\
(\mathrm{mol} / \mathrm{g}) \mathrm{x} \\
10^{-11}\end{array}$ & ${ }^{40}{ }^{40} \mathbf{A r}_{\text {rad }} /$ & $\begin{array}{l}\text { Age } \\
\text { (Ma) }\end{array}$ & $\begin{array}{c} \pm 1 \\
(\mathrm{~m} . \mathbf{y} .)\end{array}$ \\
\hline DT 76-31 & 77157 & 59.9217 & 160.9017 & $\begin{array}{l}\text { biotite-muscovite } \\
\text { gneiss }\end{array}$ & $\begin{array}{l}\text { biotite } \\
\text { (impure) }\end{array}$ & 4 & 8.686 & 259.90 & 0.941 & 196.7 & 5.8 \\
\hline DT 76-34 & 77095 & 59.9250 & 160.8983 & biotite gneiss & biotite & 2 & 5.190 & 109.40 & 0.703 & 140.8 & 4.1 \\
\hline DT 76-36 & & 59.9300 & 160.8950 & $\begin{array}{l}\text { biotite-muscovite- } \\
\text { quartz schist }\end{array}$ & muscovite & 4 & 9.793 & 230.50 & 0.858 & 156.5 & 4.6 \\
\hline DT 76-36 & 77158 & 59.9300 & 160.8950 & $\begin{array}{c}\text { biotite-muscovite- } \\
\text { quartz schist }\end{array}$ & $\begin{array}{l}\text { biotite } \\
\text { (impure) }\end{array}$ & 4 & 7.398 & 471.00 & 0.926 & 395.5 & 12.0 \\
\hline DT 76-39 & 77096 & 59.9133 & 160.8967 & granodiorite gneiss & biotite & 2 & 8.639 & 394.70 & 0.959 & 292.3 & 8.6 \\
\hline DT 76-41 & 77097 & 59.9467 & 160.9117 & $\begin{array}{l}\text { biotite-hornblende- } \\
\text { epidote schist }\end{array}$ & hornblende & 2 & 0.730 & 14.12 & 0.889 & 129.6 & 3.8 \\
\hline DT 76-41 & 77149 & 59.9467 & 160.9117 & $\begin{array}{l}\text { biotite-hornblende- } \\
\text { epidote schist }\end{array}$ & biotite & 4 & 7.893 & 188.50 & 0.924 & 158.7 & 4.7 \\
\hline DT 76-42 & 77152 & 59.9467 & 160.9133 & $\begin{array}{l}\text { biotite-muscovite } \\
\text { granodiorite gneiss }\end{array}$ & biotite & 4 & 8.431 & 172.10 & 0.943 & 136.5 & 4.0 \\
\hline DT 76-46 & 77155 & 59.9400 & 160.9233 & $\begin{array}{l}\text { biotite-hornblende- } \\
\text { muscovite schist }\end{array}$ & hornblende & 3 & 0.606 & 17.67 & 0.848 & 191.9 & 5.6 \\
\hline DT 76-46 & 77078 & 59.9400 & 160.9233 & $\begin{array}{l}\text { biotite-hornblende- } \\
\text { muscovite schist }\end{array}$ & biotite & 2 & 8.495 & 291.20 & 0.911 & 223.6 & 6.6 \\
\hline DT 76-52 & & 59.9217 & 160.8867 & $\begin{array}{l}\text { quartz-muscovite } \\
\text { gneiss }\end{array}$ & muscovite & 4 & 9.522 & 185.60 & 0.923 & 130.5 & 3.9 \\
\hline DT 76-56 & 77084 & 59.9700 & 160.8467 & $\begin{array}{l}\text { biotite-muscovite- } \\
\text { hornblende schist }\end{array}$ & muscovite & 3 & 9.839 & 278.90 & 0.914 & 186.9 & 5.5 \\
\hline DT 76-56 & 77156 & 59.9700 & 160.8467 & $\begin{array}{l}\text { biotite-muscovite- } \\
\text { hornblende schist }\end{array}$ & biotite & 4 & 8.281 & 462.30 & 0.938 & 351.2 & 10.3 \\
\hline DT 76-57 & 77101 & 59.9550 & 160.8983 & $\begin{array}{l}\text { quartz-muscovite- } \\
\text { biotite gneiss }\end{array}$ & muscovite & 4 & 10.549 & 200.90 & 0.880 & 127.7 & 3.9 \\
\hline
\end{tabular}


Table 1. Analytical data for K-Ar analyses of samples from Kanektok complex (cont.).

\begin{tabular}{|c|c|c|c|c|c|c|c|c|c|c|c|}
\hline Sample No. & $\begin{array}{l}\text { Lab } \\
\text { No. }\end{array}$ & $\underset{{ }^{\circ} \mathbf{N}}{\text { Latitude }}$ & $\begin{array}{c}\text { Longitude } \\
{ }^{\circ} \mathbf{W}\end{array}$ & Rock Type & Mineral & $\mathbf{x}$ & $\begin{array}{c}\mathrm{K}_{2} \mathrm{O} \\
(\mathbf{w t .} \%)\end{array}$ & $\begin{array}{c}{ }^{40} \mathrm{Ar}_{\mathrm{rad}} \\
(\mathrm{mol} / \mathrm{g}) \mathrm{x} \\
\mathbf{1 0}^{-11}\end{array}$ & ${ }^{{ }^{40} \mathbf{A} \mathbf{r}_{\text {rad }} /}$ & $\begin{array}{l}\text { Age } \\
\text { (Ma) }\end{array}$ & $\begin{array}{c} \pm 1 \\
(\mathrm{~m} \cdot \mathrm{y} \cdot)\end{array}$ \\
\hline DT 76-57 & 77099 & 59.9550 & 160.8983 & $\begin{array}{c}\text { biotite-muscovite } \\
\text { gneiss }\end{array}$ & biotite & 2 & 9.134 & 179.90 & 0.876 & 131.9 & 3.9 \\
\hline DT 76-58 & 77100 & 59.9533 & 160.8933 & hornblende diorite & hornblende & 4 & 0.612 & 11.74 & 0.799 & 128.6 & 3.8 \\
\hline DT 76-61 & 77106 & 59.9450 & 160.8817 & $\begin{array}{c}\text { porphyroblastic } \\
\text { amphibolite }\end{array}$ & hornblende & 2 & 0.393 & 12.05 & 0.911 & 201.3 & 5.9 \\
\hline DT 76-62 & 77079 & 59.9050 & 160.9033 & amphibolite & hornblende & 2 & 0.340 & 35.41 & 0.937 & 608.3 & 18.0 \\
\hline DT 76-66 & 77105 & 59.9017 & 160.9017 & $?$ & biotite & 2 & 8.815 & 335.10 & 0.961 & 246.4 & 7.2 \\
\hline DT 76-69A & 77083 & 59.9000 & 160.8967 & garnet amphibolite & hornblende & 2 & 0.280 & 121.30 & 0.972 & 1770.3 & 53 \\
\hline DT 76-70 & 77165 & 60.0933 & 160.6000 & biotite amphibolite & biotite & 2 & 7.836 & 939.00 & 0.964 & 684.4 & 20.0 \\
\hline DT 76-70 & 77072 & 60.0933 & 160.6000 & biotite amphibolite & hornblende & 2 & 0.715 & 122.70 & 0.893 & 915.1 & 27.0 \\
\hline DT 76-71 & 77161 & 60.0950 & 160.6283 & $\begin{array}{c}\text { biotite-hornblende } \\
\text { gneiss }\end{array}$ & hornblende & 4 & 0.595 & 24.53 & 0.900 & 265.8 & 7.8 \\
\hline DT 76-72 & 77093 & 60.1267 & 160.5667 & $\begin{array}{l}\text { biotite-hornblende- } \\
\text { epidote-plagioclase } \\
\text { rock }\end{array}$ & biotite & 4 & 8.234 & 177.10 & 0.487 & 143.5 & 4.2 \\
\hline DT 76-72 & 77094 & 60.1267 & 160.5667 & $\begin{array}{l}\text { biotite-hornblende- } \\
\text { epidote-plagioclase } \\
\text { rock }\end{array}$ & hornblende & 2 & 0.595 & 13.71 & 0.899 & 153.3 & 4.5 \\
\hline DT 76-74 & 77092 & 60.1267 & 160.5667 & $\begin{array}{c}\text { biotite-hornblende- } \\
\text { epidote rock }\end{array}$ & biotite & 4 & 8.798 & 214.70 & 0.900 & 162.0 & 4.7 \\
\hline DT 76-74 & 77081 & 60.1267 & 160.5667 & $\begin{array}{c}\text { biotite-hornblende- } \\
\text { epidote rock }\end{array}$ & hornblende & 4 & 0.608 & 31.53 & 0.935 & 328.4 & 9.7 \\
\hline DT 76-76 & 77086 & 59.8567 & 160.9033 & garnet amphibolite & hornblende & 4 & 0.463 & 50.83 & 0.941 & 636.0 & 19.0 \\
\hline
\end{tabular}




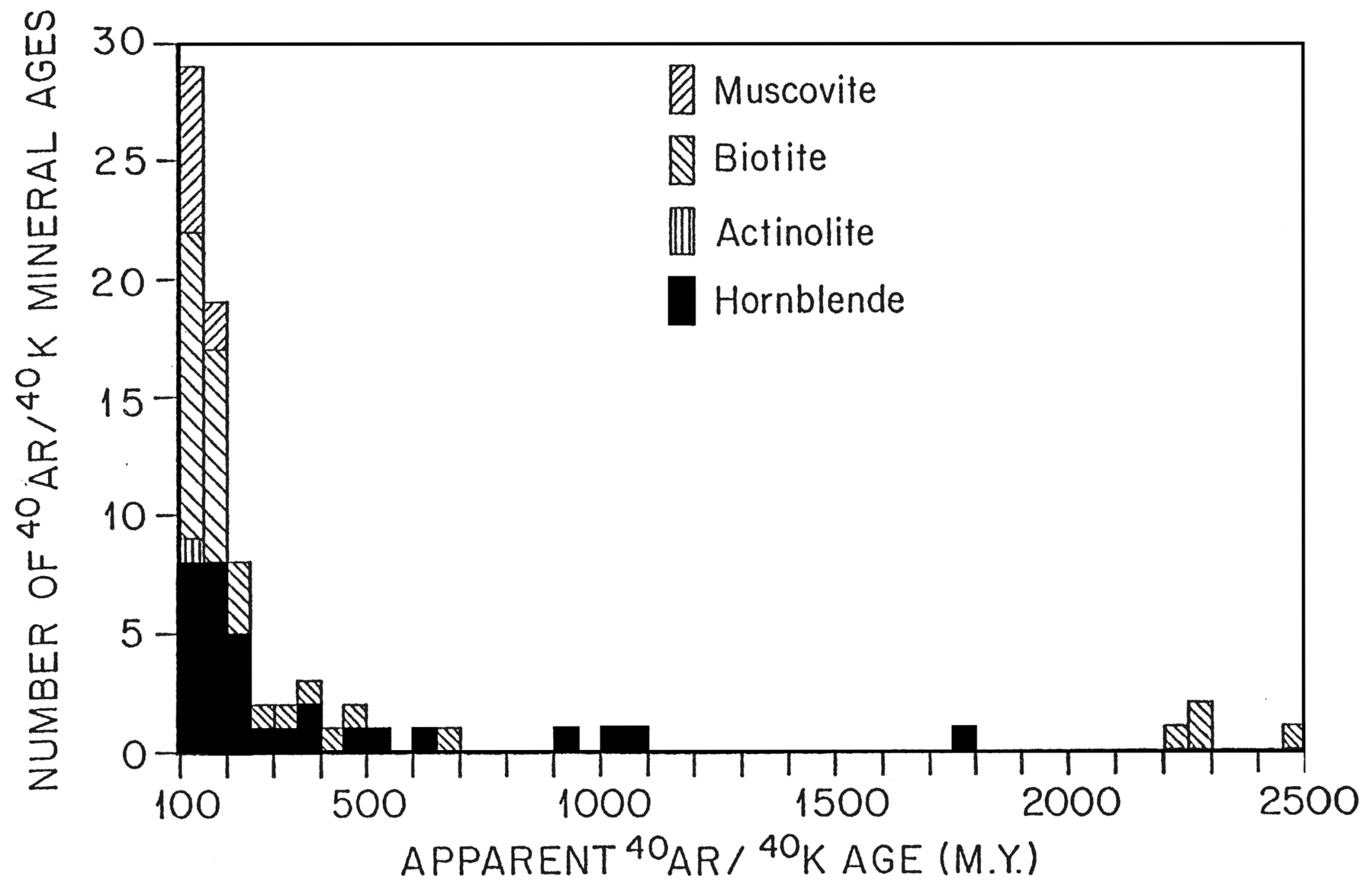

Figure 5. Histogram of 77 apparent ${ }^{40} \mathrm{Ar} /{ }^{40} \mathrm{~K}$ mineral ages from all major outcrop areas of the Kanektok complex. 


\section{Evidence for Excess ${ }^{40} \mathrm{Ar}$}

Five pyroxene granulites have apparent Precambrian biotite ages $(685,2,203$, 2,255, 2,271 and 2,474 m.y). Argon analyses for four of the five biotite samples were each repeated 2 to 5 times. Each of these four biotite samples shows an extremely variable content of radiogenic ${ }^{40} \mathrm{Ar} / \mathrm{g}$. $(6.2 \%, 9.9 \%, 22.7 \%$ and $46.3 \%$ spreads, table 1$)$. Two samples of biotite from gneiss sample DT 75-61 gave a mean age of 2,271 Ma with a $6.2 \%$ spread in radiogenic ${ }^{40} \mathrm{Ar} / \mathrm{g}$ (table 1). A garnet amphibolite interlayered with the gneiss at the same locality, however, gave a hornblende age of only $170 \mathrm{Ma}$. These results strongly suggest the incorporation of variable amounts of excess ${ }^{40} \mathrm{Ar}$ which is distributed in a non-homogeneous way throughout the biotites in each of these rocks.

The hypothesis that these biotites contain excess argon is supported by the fact that only one of the dated hornblendes gives an age greater than 1,100 $\mathrm{Ma}$, and its age (1770 Ma) is significantly younger than the 2,200-2,500 Ma apparent ages of most of the above biotites. Because hornblendes are known to be more resistant than biotites to thermal overprinting, one would normally expect hornblende K-Ar ages to be older than biotite ages in a complex metamorphic terrane such as this. There are no biotite ages in the 700-2,200 Ma interval, but there are four hornblende ages in this interval (fig. 5).

Studies of 3,700 m.y. old gneisses from Greenland by Pankhurst and others (1973) have found clear evidence of excess radiogenic ${ }^{40} \mathrm{Ar}$ in metamorphic biotites. Most of their biotite ${ }^{40} \mathrm{Ar} /{ }^{39} \mathrm{Ar}$ ages exceeded hornblende ages from the same rock suites, and one of these biotites yielded an impossibly old age of 4,940 Ma. Russian workers have found similar results in Precambrian biotites from gneisses of the Baltic Shield (Lobach-Zhuchenko and others, 1972). They found 4,800-5,200 Ma K-Ar biotite ages from one area, while $\mathrm{Rb}-\mathrm{Sr}$ whole-rock and U-Pb zircon studies on biotite-bearing gneisses and granites gave 2,600-2,700 Ma ages. These rocks were shown to have undergone metamorphic overprinting about 1,800 m.y. ago.

Five Kanektok complex amphibolites have apparent Precambrian hornblende ages $(637,915,1,049,1,089$ and 1,770 Ma). Four of these hornblendes were analyzed for argon in duplicate. All duplicates show reproducible radiogenic ${ }^{40} \mathrm{Ar}$ content within analytical uncertainty (table 1). These hornblendes do not appear to be subject to the excess argon problem found in the biotites.

The hornblende ages strongly suggest that the amphibolite facies core zone of the complex is Precambrian, probably at least 1 b.y. old and possibly as much as 1.77 b.y. old, as confirmed by the U-Pb and Rb-Sr results to be discussed later. Most K-Ar mineral ages from the terrane, however have been overprinted by a pervasive late Mesozoic thermal event, accompanied by plutonism, which appears to have totally reset most of the K-Ar ages and may have partially reset the remainder (fig. 5).

\section{${ }^{40} \mathrm{Ar} /{ }^{39} \mathrm{Ar}$ Studies}

A six-step ${ }^{40} \mathrm{Ar} /{ }^{39} \mathrm{Ar}$ incremental heating study of a biotite sample (DT 75-72) yielding a conventional ${ }^{40} \mathrm{~K} /{ }^{40} \mathrm{Ar}$ age of approximately $2.5 \mathrm{Ga}$ was done by D.L. Turner at the Isotope Geology Laboratory of the U.S. Geological Survey, Menlo Park, California. Analytical data are given in table 2; analytical methods are described by Lanphere and Dalrymple (1971). ${ }^{3}$ The heating spectrum appears to be more-or-less "normal", with a

\footnotetext{
${ }^{3}$ Many advances in the application of ${ }^{40} \mathrm{Ar}-{ }^{39} \mathrm{Ar}$ dating have been made since this manuscript was prepared; see for example, Faure, Gunter and Mensing, T.K., 2005, Isotopes, principles and applications ( $3^{\text {rd }}$ ed.): Hoboken, New Jersey, John Wiley and Sons, Inc., 896 p.
} 
fairly good plateau at about $2.52 \mathrm{Ga}$ (fig. 6). The lower age of the first step suggests a partial loss of radiogenic ${ }^{40} \mathrm{Ar}$ during a later thermal event. There is no obvious evidence of excess ${ }^{40} \mathrm{Ar}$, such as anomalously old ages from the lower temperature gas releases. This result night appear to be consistent with the interpretation that the dated rock was recrystallized at least 2.5 billion years ago. However, recent studies of biotite release spectra from metamorphic rocks (Lanphere and Dalrymple, 1971; Pankhurst and others, 1973; Hanson and others, 1971; Tetley, 1978) raise serious questions regarding the suitability of biotites for this type of analysis. It appears that many, if not all, biotite ${ }^{40} \mathrm{Ar} /{ }^{39} \mathrm{Ar}$ incremental heating plateaus are experimental artifacts resulting from chemical and/or physical changes occurring in the biotite structure during heating in a vacuum. It now seems clear that the ${ }^{40} \mathrm{Ar} /{ }^{39} \mathrm{Ar}$ technique is unable to resolve excess from in-situ radiogenic ${ }^{40} \mathrm{Ar}$ in biotites from regionally recrystallized metamorphic rocks, and that a ${ }^{40} \mathrm{Ar} /{ }^{39} \mathrm{Ar}$ incremental heating plateau for biotite cannot be regarded as indicating a geologically meaningful age.

In view of the evidence discussed above and the $\mathrm{U}-\mathrm{Pb}$ and $\mathrm{Rb}-\mathrm{Sr}$ results to be discussed later, it is clear that the apparent Precambrian biotite ages from the Kanektok metamorphic complex have been artificially increased by excess radiogenic ${ }^{40} \mathrm{Ar}$ formed by degassing of basement rocks during metamorphism. These biotite ages should therefore be considered unreliable.

Three additional samples were selected for ${ }^{40} \mathrm{Ar} /{ }^{39} \mathrm{Ar}$ incremental heating studies in an attempt to obtain meaningful high-temperature plateau ages that might help in the interpretation of the complex history of the terrane. It was hoped that the early-to-middle Proterozoic [Paleoproterozoic] metamorphic event indicated by the $\mathrm{U}-\mathrm{Pb}$ and $\mathrm{Rb}-\mathrm{Sr}$ studies to be discussed later and by the oldest conventional ${ }^{40} \mathrm{~K} /{ }^{40} \mathrm{Ar}$ hornblende age might be reflected in the high-temperature gas releases from one or more mineral samples whose conventional ${ }^{40} \mathrm{~K} /{ }^{40} \mathrm{Ar}$ ages were intermediate between $1.77 \mathrm{Ga}$ and the late Mesozoic thermal event. Accordingly, the following core zone samples were analyzed:

- DT 75-70 biotite from a quartz monzonite gneiss yielded a ${ }^{40} \mathrm{Ar} /{ }^{39} \mathrm{Ar}$ total fusion age of $487 \mathrm{Ma}$.

- DT 75-69 hornblende from a garnet amphibolite yielded a ${ }^{40} \mathrm{Ar} /{ }^{39} \mathrm{Ar}$ total fusion age of $478 \mathrm{Ma}$.

- DT 75-76 hornblende from a garnet amphibolite yielded a ${ }^{40} \mathrm{Ar} /{ }^{39} \mathrm{Ar}$ total fusion age of 1,124 Ma.

Analytical work was done by D.L. Turner and Ian McDougall at The Research School of Earth Sciences, Australian National University, Canberra. Analytical data for ${ }^{40} \mathrm{Ar} /{ }^{39} \mathrm{Ar}$ analyses are given in table 2. Analytical techniques are described in Harrison and McDougall (1980).

The ${ }^{40} \mathrm{Ar} /{ }^{39} \mathrm{Ar}$ age spectrum for DT 75-70 biotite is shown in figure 7 . The spectrum rises from an initial age of $152 \pm 87 \mathrm{Ma}$ to a plateau age of $496 \pm 1.5 \mathrm{Ma}$, defined by nine of the thirteen gas release steps. The plateau age does not differ greatly from the ${ }^{40} \mathrm{Ar} /{ }^{39} \mathrm{Ar}$ total fusion age of $487 \pm 4.3 \mathrm{Ma}$. The lower ages of the first three steps suggest partial loss of radiogenic ${ }^{40} \mathrm{Ar}$ during a later thermal event. The spectrum is consistent with the hypothesis that this event is the late Mesozoic intrusive episode which has reset most of the conventional ages (fig. 5). The plateau age of 496 Ma probably represents a minimum age of metamorphic recrystallization for the biotite. However, in view of the problems discussed previously, age spectra from this mineral must be interpreted with caution. 


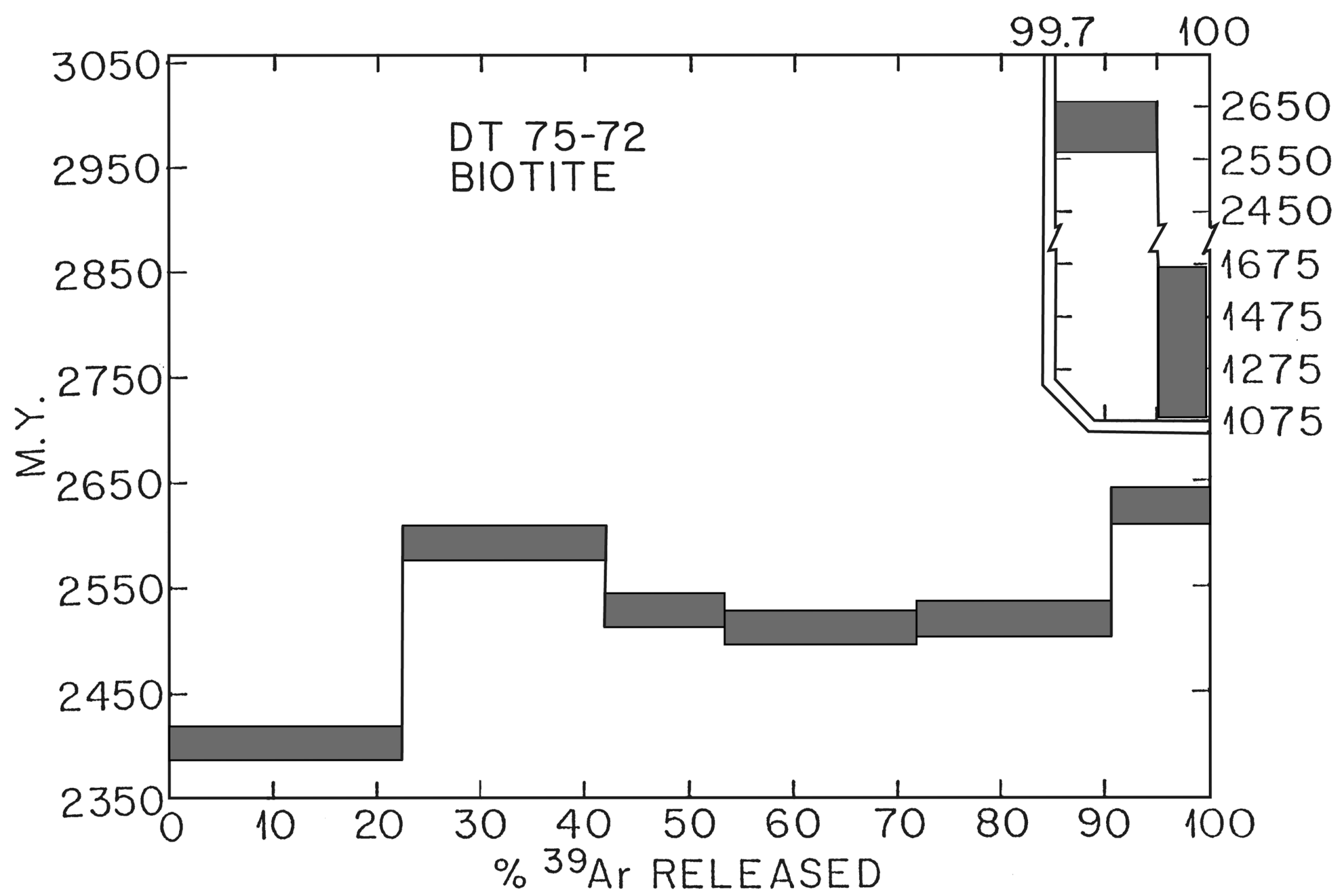

Figure 6. ${ }^{40} \mathrm{Ar} /{ }^{39} \mathrm{Ar}$ incremental heating release spectrum for $\mathrm{DT} 75-72$ biotite $\left({ }^{40} \mathrm{Ar} /{ }^{40} \mathrm{~K}\right.$ total fusion age 2.5 b.y.). 
Table 2. Analytical data for ${ }^{40} \mathrm{Ar} /{ }^{39} \mathrm{Ar}$ age spectra.

$\left[{ }^{1}\right.$ Uncorrected for line blank; ${ }^{2}$ Corrected for decay 37Ar; ${ }^{3}$ Obtained by manometric measurement of gas calibrated using $38 \mathrm{Ar}$ tracer; ${ }^{4}$ Uncertainties quoted at the level of standard deviation; ${ }^{5} \mathrm{FM}-$ flux monitor GA1550 biotite; K/Ca $=38.5 ;{ }^{6} \mathrm{TF}-$ total fusion run with air leak in extraction line; ${ }^{7} \mathrm{FM}$ - flux monitor 77-600 hornblende; $\mathrm{K} / \mathrm{Ca}=0.037$ ]

\begin{tabular}{|c|c|c|c|c|c|c|c|c|c|c|}
\hline Sample No. & $\begin{array}{c}\text { Step } \\
\text { Temperature } \\
\left({ }^{\circ} \mathrm{C}\right) \\
\end{array}$ & ${ }^{40} \mathrm{Ar} /{ }^{39} \mathrm{Ar}{ }^{1}$ & ${ }^{37} \mathbf{A r} /{ }^{39} \mathbf{A} \mathbf{r}^{2}$ & $\begin{array}{c}{ }^{36} \mathrm{Ar} /{ }^{39} \mathrm{Ar}^{1} \\
\left(\mathbf{x} 10^{-1}\right)\end{array}$ & $\begin{array}{c}{ }^{39} \mathrm{Ar}^{3} \\
\left(\times 10^{-14} \mathrm{~mol}\right)\end{array}$ & $\begin{array}{l}\text { Cumulative } \\
{ }^{39} \mathrm{Ar} \quad(\%)\end{array}$ & $\begin{array}{l}{ }^{40} \mathrm{Ar} * / \\
{ }^{40} \mathbf{A r}_{\text {total }} \\
(\%)\end{array}$ & ${ }^{{ }^{40} \mathrm{Ar} /}$ & $\begin{array}{l}\text { Age } \\
\text { (Ma) }\end{array}$ & $\begin{array}{c}\text { Standard } \\
\text { error }^{4} \\
\text { (m.y.) } \\
\end{array}$ \\
\hline \multicolumn{11}{|c|}{$\begin{array}{c}\text { DT } 75-70 \text { Biotite } \\
\text { Latitude } 59.5583^{\circ} \mathrm{N} . ; \\
\text { Longitude } 161.3800^{\circ} \mathrm{W} .\end{array}$} \\
\hline & $\mathrm{FM}^{5}$ & 14.22 & 0.0177 & 0.0858 & 459.6 & & 82.0 & 11.66 & & $(0.15 \%)$ \\
\hline & $\mathrm{TF}^{6}$ & 87.15 & 0.00514 & 0.7519 & 59.34 & & 74.5 & 64.91 & 486.6 & 4.3 \\
\hline & 525 & 1707.01 & & 57.15 & 4.862 & 0.446 & 1.08 & 18.39 & 151.7 & 87.0 \\
\hline & 600 & 508.1 & 0.021 & 15.55 & 32.18 & 3.40 & 9.55 & 48.50 & 375.5 & 12.3 \\
\hline & 655 & 236.0 & 0.00480 & 5.881 & 143.4 & 16.6 & 26.3 & 62.15 & 459.7 & 6.12 \\
\hline & 760 & 80.84 & 0.00207 & 0.5274 & 268.1 & 41.2 & 80.7 & 65.22 & 488.7 & 4.33 \\
\hline & 800 & 67.28 & 0.00398 & 0.0304 & 304.0 & 69.0 & 98.6 & 66.36 & 496.1 & 4.36 \\
\hline & 830 & 69.91 & & 0.0536 & 15.03 & 70.4 & 97.7 & 58.29 & 508.7 & 4.48 \\
\hline & 870 & 63.31 & 0.013 & 0.0378 & 77.03 & 77.5 & 98.4 & 68.17 & 507.9 & 4.45 \\
\hline & 910 & 68.60 & 0.014 & 0.0533 & 44.42 & 81.6 & 97.7 & 67.00 & 500.3 & 4.40 \\
\hline & 945 & 67.20 & 0.020 & 0.0511 & 49.34 & 86.1 & 97.7 & 65.67 & 491.6 & 4.33 \\
\hline & 990 & 56.51 & 0.013 & 0.0471 & 79.62 & 93.4 & 97.8 & 65.08 & 487.7 & 4.29 \\
\hline & 1060 & 67.05 & 0.00834 & 0.0690 & 35.83 & 96.8 & 96.9 & 64.99 & 487.1 & 4.29 \\
\hline & 1145 & 71.43 & 0.0430 & 0.1481 & 32.89 & 99.8 & 93.8 & 67.03 & 500.5 & 4.40 \\
\hline & 1250 & 85.46 & 0.377 & 0.5029 & 2.24 & 100.0 & 82.6 & 70.63 & 523.8 & 7.01 \\
\hline
\end{tabular}


Table 2. Analytical data for ${ }^{40} \mathrm{Ar} /{ }^{39} \mathrm{Ar}$ age spectra (cont.).

\begin{tabular}{|c|c|c|c|c|c|c|c|c|c|c|}
\hline Sample No. & $\begin{array}{c}\text { Step } \\
\text { Temperature } \\
\left({ }^{\circ} \mathrm{C}\right) \\
\end{array}$ & ${ }^{40} \mathrm{Ar} /{ }^{39} \mathrm{Ar}{ }^{1}$ & ${ }^{37} \mathrm{Ar} /{ }^{39} \mathrm{Ar}{ }^{2}$ & $\begin{array}{c}{ }^{36} \mathrm{Ar} /{ }^{39} \mathrm{Ar}^{1} \\
\left(\mathbf{x 1 0} 0^{-1}\right)\end{array}$ & $\begin{array}{c}{ }^{39} \mathrm{Ar}^{3} \\
\left(\times 10^{-14} \mathrm{~mol}\right)\end{array}$ & $\begin{array}{l}\text { Cumulative } \\
{ }^{39} \mathrm{Ar} \quad(\%)\end{array}$ & $\begin{array}{l}{ }^{40} \mathrm{Ar} * / \\
{ }^{40} \mathbf{A r}_{\text {total }} \\
(\%)\end{array}$ & ${ }^{{ }^{40} \mathrm{Ar} /}$ & $\begin{array}{l}\text { Age } \\
\text { (Ma) }\end{array}$ & $\begin{array}{c}\text { Standard } \\
\text { error }^{4} \\
\text { (m.y.) }\end{array}$ \\
\hline \multicolumn{11}{|c|}{$\begin{array}{c}\text { DT } 75-72 \text { Biotite } \\
\text { Latitude } 59.5600^{\circ} \mathrm{N} . ; \\
\text { Longitude } 161.3550^{\circ} \mathrm{W} \text {. }\end{array}$} \\
\hline & 500 & 342.9 & 0.01134 & 0.06397 & 0.2082 & 22.5 & 99.4 & 342.0 & 2401 & 16.3 \\
\hline & 500 & 394.0 & 0.04039 & 0.04991 & 0.1787 & 41.8 & 99.6 & 394.0 & 2589 & 16.9 \\
\hline & 700 & 375.9 & 0.01911 & 0.04111 & 0.1078 & 53.4 & 99.7 & 375.9 & 2524 & 16.7 \\
\hline & 775 & 372.3 & 0.01584 & 0.03817 & 0.1697 & 71.7 & 99.7 & 372.3 & 2511 & 16.6 \\
\hline & 850 & 373.7 & 0.01455 & 0.03458 & 0.1749 & 90.6 & 99.7 & 373.7 & 2516 & 16.5 \\
\hline & 950 & 404.5 & 0.05391 & 0.03949 & 0.08452 & 99.7 & 99.7 & 404.5 & 2625 & 18.6 \\
\hline & 1025 & 399.6 & 1.248 & 1.629 & 0.001675 & 99.9 & 89.3 & 399.9 & 2609 & 49.9 \\
\hline & Fusion & 766.2 & $3.763 \times 10^{-8}$ & 2.119 & 0.0004836 & 100.0 & 18.3 & 140.1 & 1371 & 294 \\
\hline
\end{tabular}


Table 2. Analytical data for ${ }^{40} \mathrm{Ar}{ }^{39} \mathrm{Ar}$ age spectra (cont.).

\begin{tabular}{|c|c|c|c|c|c|c|c|c|c|c|}
\hline Sample No. & $\begin{array}{c}\text { Step } \\
\text { Temperature } \\
\left({ }^{\circ} \mathrm{C}\right)\end{array}$ & ${ }^{40} \mathrm{Ar} /{ }^{39} \mathrm{Ar}{ }^{1}$ & ${ }^{37} \mathbf{A r} /{ }^{39} \mathbf{A} \mathbf{r}^{2}$ & $\begin{array}{c}{ }^{36} \mathrm{Ar} /{ }^{39} \mathrm{Ar}^{1} \\
\left(\mathbf{x 1 0} 0^{-1}\right)\end{array}$ & $\begin{array}{c}{ }^{39} \mathrm{Ar}^{3} \\
\left(\times 10^{-14} \mathrm{~mol}\right)\end{array}$ & $\begin{array}{l}\text { Cumulative } \\
{ }^{39} \mathrm{Ar} \quad(\%)\end{array}$ & $\begin{array}{l}{ }^{40} \mathrm{Ar} * / \\
{ }^{40} \mathbf{A r}_{\text {total }}\end{array}$ & $\begin{array}{l}{ }^{40} \mathrm{Ar} / \\
{ }^{39} \mathrm{Ar}\end{array}$ & $\begin{array}{l}\text { Age } \\
\text { (Ma) }\end{array}$ & $\begin{array}{c}\text { Standard } \\
\text { error }^{4} \\
(\mathbf{m . y .})\end{array}$ \\
\hline \multicolumn{11}{|c|}{$\begin{array}{l}\text { DT } 75-69 \text { Hornblende } \\
\text { Latitude } 59.5633^{\circ} \mathrm{N} . ; \\
\text { Longitude } 161.3800^{\circ} \mathrm{W} \text {. }\end{array}$} \\
\hline & $\mathrm{FM}^{7}$ & 56.84 & 13.85 & 0.1790 & 87.46 & & 92.8 & 53.31 & & $(0.12 \%)$ \\
\hline & TF & 64.54 & 5.282 & 0.0867 & 125.1 & & 96.7 & 62.67 & 47.80 & 4.23 \\
\hline & 690 & 56.52 & 1.440 & 0.5656 & 19.90 & 2.25 & 70.6 & 39.94 & 318.9 & 3.29 \\
\hline & 790 & 36.32 & 0.9625 & 0.4439 & 23.25 & 4.89 & 64.1 & 23.28 & 192.7 & 10.8 \\
\hline & 860 & 46.13 & 1.797 & 0.5788 & 15.05 & 6.60 & 63.2 & 29.20 & 238.5 & 2.48 \\
\hline & 910 & 62.07 & 3.853 & 0.5490 & 11.46 & 7.89 & 74.4 & 46.29 & 364.8 & 3.81 \\
\hline & 930 & 70.47 & 4.865 & 0.4925 & 8.254 & 8.82 & 79.9 & 56.53 & 436.4 & 4.11 \\
\hline & 970 & 69.76 & 5.503 & 0.1163 & 38.91 & 13.2 & 95.7 & 67.06 & 507.2 & 4.47 \\
\hline & 1010 & 70.89 & 5.574 & 0.08452 & 74.55 & 21.6 & 97.1 & 69.15 & 520.9 & 4.57 \\
\hline & 1030 & 71.53 & 5.559 & 0.07595 & 47.55 & 27.0 & 97.5 & 70.01 & 526.5 & 4.60 \\
\hline & 1040 & 70.36 & 5.558 & 0.07332 & 50.34 & 32.7 & 97.6 & 68.94 & 519.6 & 4.55 \\
\hline & 1070 & 67.84 & 5.601 & 0.06405 & 102.2 & 44.2 & 97.9 & 66.70 & 504.8 & 4.43 \\
\hline & 1080 & 65.45 & 5.558 & 0.05653 & 86.78 & 54.0 & 98.2 & 64.52 & 490.4 & 4.31 \\
\hline & 1100 & 62.55 & 5.554 & 0.05433 & 84.40 & 63.5 & 98.2 & 61.66 & 471.3 & 4.17 \\
\hline & 1110 & 60.04 & 5.517 & 0.04936 & 104.5 & 75.3 & 98.4 & 59.29 & 455.2 & 4.05 \\
\hline & 1400 & 61.61 & 5.561 & 0.07475 & 219.3 & 100.0 & 97.2 & 60.12 & 460.8 & 4.09 \\
\hline
\end{tabular}


Table 2. Analytical data for ${ }^{40} \mathrm{Ar} /{ }^{39} \mathrm{Ar}$ age spectra (cont.).

\begin{tabular}{|c|c|c|c|c|c|c|c|c|c|c|}
\hline Sample No. & $\begin{array}{c}\text { Step } \\
\text { Temperature } \\
\left({ }^{\circ} \mathrm{C}\right) \\
\end{array}$ & ${ }^{40} \mathrm{Ar} /{ }^{39} \mathbf{A} \mathbf{r}^{1}$ & ${ }^{37} \mathbf{A r} /{ }^{39} \mathbf{A} \mathbf{r}^{2}$ & $\begin{array}{c}{ }^{36} \mathrm{Ar} /{ }^{39} \mathrm{Ar}^{1} \\
\left(\mathbf{x 1 0} 0^{-1}\right)\end{array}$ & $\begin{array}{c}{ }^{39} \mathrm{Ar}^{3} \\
\left(\times 10^{-14} \mathrm{~mol}\right)\end{array}$ & $\begin{array}{l}\text { Cumulative } \\
{ }^{39} \mathrm{Ar} \quad(\%)\end{array}$ & $\begin{array}{l}{ }^{40} \mathrm{Ar} * / \\
{ }^{40} \mathbf{A r}_{\text {total }} \\
(\%)\end{array}$ & ${ }^{40} \mathrm{Ar} /$ & $\begin{array}{l}\text { Age } \\
\text { (Ma) }\end{array}$ & $\begin{array}{c}\text { Standard } \\
\text { error }^{4} \\
\text { (m.y.) }\end{array}$ \\
\hline \multicolumn{11}{|c|}{$\begin{array}{l}\text { DT 75-76 Hornblende } \\
\text { Latitude } 59.5467^{\circ} \mathrm{N} . ; \\
\text { Longitude } 161.4033^{\circ} \mathrm{W} \text {. }\end{array}$} \\
\hline & $\mathrm{FM}^{7}$ & 59.72 & 13.86 & 0.2519 & 94.26 & & 89.6 & 54.05 & & $(0.11 \%)$ \\
\hline & $\mathrm{TF}$ & 184.0 & 4.209 & 0.1252 & 64.49 & & 98.2 & 181.18 & 1123 & 8.4 \\
\hline & 500 & 1130 & 6.281 & 20.63 & 0.4339 & 0.086 & 46.1 & 523.6 & 2260 & 94.8 \\
\hline & 550 & 503.7 & 3.934 & 7.792 & 0.3747 & 0.160 & 54.3 & 274.5 & 1624 & 44.0 \\
\hline & 630 & 502.6 & 3.395 & 8.403 & 0.4703 & 0.253 & 50.7 & 262.6 & 1466 & 31.3 \\
\hline & 680 & 1129 & 2.536 & 31.43 & 1.000 & 0.451 & 17.7 & 194.7 & 1186 & 41.0 \\
\hline & 780 & 2869 & 3.052 & 93.58 & 1.122 & 0.673 & 3.64 & 104.6 & 731.0 & 221 \\
\hline & 810 & 253.9 & 3.813 & 2.838 & 0.9085 & 0.851 & 67.1 & 172.2 & 1083 & 180 \\
\hline & 860 & 215.2 & 4.622 & 1.261 & 3.108 & 1.46 & 82.9 & 178.9 & 1114 & 9.1 \\
\hline & 910 & 194.1 & 4.304 & 0.1658 & 39.78 & 9.33 & 97.7 & 190.1 & 1165 & 8.6 \\
\hline & 930 & 193.1 & 4.230 & 0.1275 & 45.59 & 18.3 & 98.2 & 190.3 & 1156 & 8.7 \\
\hline & 940 & 193.0 & 4.202 & 0.1140 & 24.22 & 23.1 & 98.4 & 190.6 & 1167 & 8.6 \\
\hline & 970 & 190.5 & 4.199 & 0.0823 & 56.99 & 34.4 & 98.9 & 189.0 & 1160 & 8.6 \\
\hline & 980 & 187.9 & 4.170 & 0.0808 & 45.34 & 43.4 & 98.9 & 186.4 & 1148 & 8.5 \\
\hline & 1020 & 183.6 & 4.141 & 0.0760 & 42.40 & 51.7 & 99.0 & 182.2 & 1129 & 8.4 \\
\hline & 1070 & 176.9 & 4.131 & 0.0526 & 140.2 & 79.5 & 99.3 & 176.2 & 1101 & 8.3 \\
\hline & 1115 & 171.3 & 4.222 & 0.0639 & 95.43 & 98.5 & 99.1 & 170.3 & 1073 & 8.1 \\
\hline & 1150 & 176.0 & 4.793 & 0.1260 & 6.83 & 999.0 & 98.1 & 173.3 & 1088 & 8.4 \\
\hline & 1400 & 248.9 & 7.289 & 1.591 & 0.635 & 100.0 & 81.36 & 203.6 & 1225 & 28.0 \\
\hline
\end{tabular}




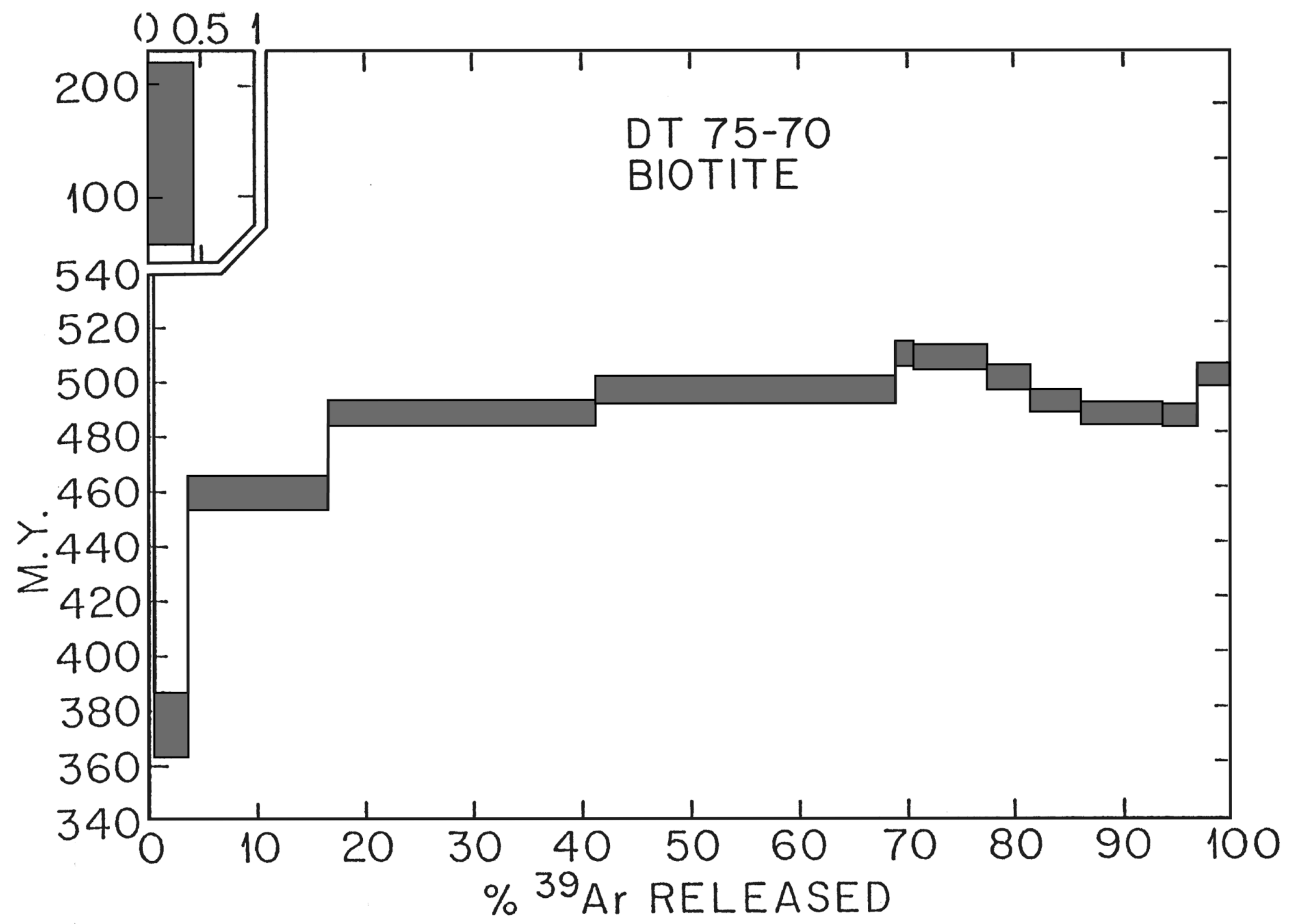

Figure 7. ${ }^{40} \mathrm{Ar} /{ }^{39} \mathrm{Ar}$ age spectrum for DT $75-70$ biotite $\left({ }^{40} \mathrm{Ar} /{ }^{39} \mathrm{Ar}\right.$ total fusion age $\left.487 \mathrm{Ma}\right)$. [Conventional $\mathrm{K}-\mathrm{Ar}$ age was $497.8 \pm 14.7 \mathrm{Ma}$ ] 
Figure 8 shows the ${ }^{40} \mathrm{Ar} /{ }^{39} \mathrm{Ar}$ age spectrum for DT 75-69 hornblende, which gave $\mathrm{a}{ }^{40} \mathrm{Ar} /{ }^{39} \mathrm{Ar}$ total fusion age of $478 \pm 4.2 \mathrm{Ma}$. Beginning with an initial age of $319 \mathrm{Ma}$ for the first $2.25 \%$ of ${ }^{39} \mathrm{Ar}$ released, the age decreases to about $200 \mathrm{Ma}$ and then increases steadily to a plateau age of $511 \pm 4.2 \mathrm{Ma}$, a value similar to the $476 \mathrm{~m} . \mathrm{y}$. plateau age for the biotite discussed above. The plateau age is defined by steps 6-11 representing $45 \%$ of the total ${ }^{39} \mathrm{Ar}$ released. Steps $12-14$, however, yield significantly younger ages $(471,455$, and $461 \mathrm{Ma}$ respectively). The low temperature part of the spectrum (steps 1-5) clearly indicates a partial loss of radiogenic ${ }^{40} \mathrm{Ar}$ from the sample during a later thermal event. The step 2 age of about $200 \mathrm{Ma}$ is interpreted as representing a maximum age for this later thermal event, and is consistent with the hypothesis that the event in question represents the late Mesozoic thermal event discussed previously. At present, we have no satisfactory explanation for the anomalously young ages for steps 12-14, representing $46 \%$ of the total ${ }^{39} \mathrm{Ar}$ released, a pattern which is also present in the spectrum of DT 7576 hornblende (fig. 9). Anomalously young ages are also present in the higher temperature heating steps of some of the Greenland hornblendes studied by Pankhurst and others (1973) but they do not discuss possible explanations for this phenomenon.

The old apparent ages of the first three steps comprising $0.25 \%$ of the total ${ }^{39} \mathrm{Ar}$ released (2.26, 1.62 and $1.47 \mathrm{Ga}$, respectively) from DT 75-76 hornblende (fig. 9) may possibly be due to recoil of ${ }^{39} \mathrm{Ar}$ out of the rims of grains during irradiation and therefore may have no geological significance. After these steps, the age spectrum drops abruptly to $731 \pm 222 \mathrm{Ma}\left(\right.$ step $5,0.22 \%{ }^{39} \mathrm{Ar}$ ), then rises abruptly to a 5 -step plateau at about 1.16 Ga comprising $41.9 \%$ of the total ${ }^{39}$ Ar released. The next four steps comprising $56.5 \%$ of the ${ }^{39} \mathrm{Ar}$ released are significantly younger $(1.13,1.10,1.07$ and $1.09 \mathrm{Ga})$. The final step gives an age of $1.22 \mathrm{Ma}$, but contains only $0.125 \%$ of the total ${ }^{39} \mathrm{Ar}$ released. The plateau age of $1.16 \mathrm{Ga}$ for this hornblende probably represents a valid minimum age for the metamorphic recrystallization of the sample but the reason for the anomalous age decrease in the latter part of the spectrum is unclear. The ${ }^{40} \mathrm{Ar} /{ }^{39} \mathrm{Ar}$ total fusion age for this sample is $1.12 \pm 0.008 \mathrm{Ga}$, a value slightly less than the plateau age.

In summary, the three ${ }^{40} \mathrm{Ar} /{ }^{39} \mathrm{Ar}$ incremental heating experiments have failed to recover high-temperature plateau ages significantly older than the ${ }^{40} \mathrm{Ar} /{ }^{39} \mathrm{Ar}$ total fusion ages of these samples. This result is surprising and was not anticipated in view of the extremely large spread in conventional ${ }^{40} \mathrm{Ar} /{ }^{40} \mathrm{~K}$ ages from this terrane.

The incremental heating experiments did not reveal any evidence for excess radiogenic ${ }^{40} \mathrm{Ar}$. In general, the four age spectra are much more uniform (flat) than was expected for samples from a terrane with such an obviously complex thermal history as revealed by the ${ }^{40} \mathrm{Ar} /{ }^{40} \mathrm{~K}$ age histogram (fig. 5).

In view of the above results, we suspect that the rather fine grain size of all the samples (150-250 mesh, or 0.104-0.061 mm) may have tended to homogenize the ${ }^{40} \mathrm{Ar}^{*}{ }^{39} \mathrm{Ar}_{\mathrm{k}}$ ratios of gas releases in these experiments. Harrison and McDougall (1980) have estimated an effective diffusion radius for spherical grains of igneous hornblendes at $0.08 \pm 0.02 \mathrm{~mm}$. If, indeed, the samples have been crushed to a size range below their effective diffusion radii, obliteration of heterogeneous Ar isotope distributions would be expected in the step heating experiments because grain cores and rims would be outgassing simultaneously. The analyzed samples were selected from mineral separates which were initially prepared for conventional K-Ar dating, in which this grain size presents no problems. We plan to prepare new hornblende separates with the coarsest possible grain size for follow-up ${ }^{40} \mathrm{Ar} /{ }^{39} \mathrm{Ar}$ step heating experiments designed to evaluate the effect of grain size on this type of analysis, and to determine whether or not significantly higher temperature plateau ages can be recovered from these samples. 


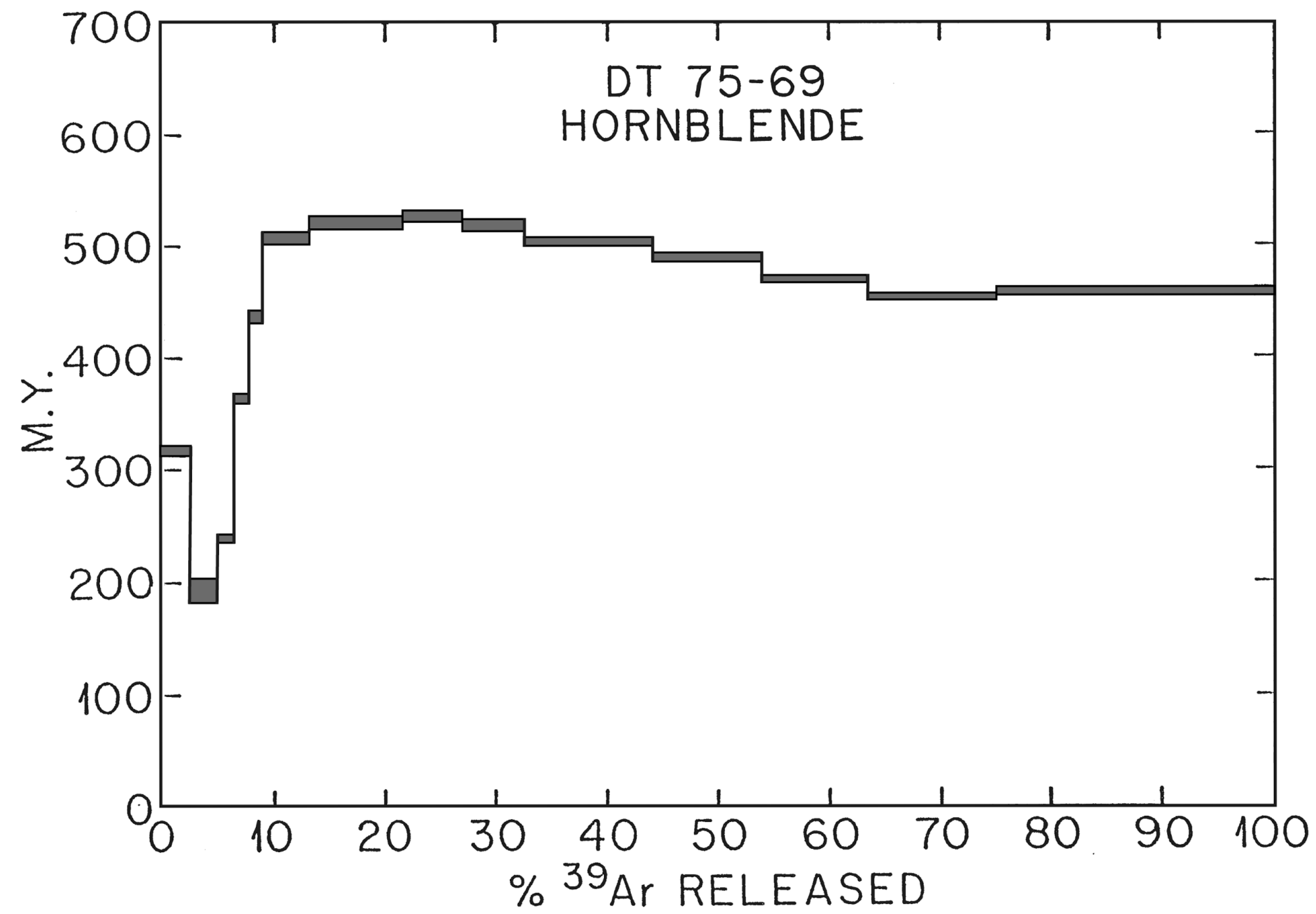

Figure 8. ${ }^{40} \mathrm{Ar} /{ }^{39} \mathrm{Ar}$ age spectrum for DT 75-69 hornblende $\left({ }^{40} \mathrm{Ar} /{ }^{39} \mathrm{Ar}\right.$ total fusion age $\left.478 \mathrm{Ma}\right)$. Steps 1-5 indicate partial loss of radiogenic ${ }^{40} \mathrm{Ar}$ from a sample at least 511 m.y. old (plateau age) during a later thermal event. Step 2 age of about $200 \mathrm{Ma}$ is interpreted as representing a maximum age for this event. The reason for the anomalous age decrease at the latter part of the spectrum is unclear. 


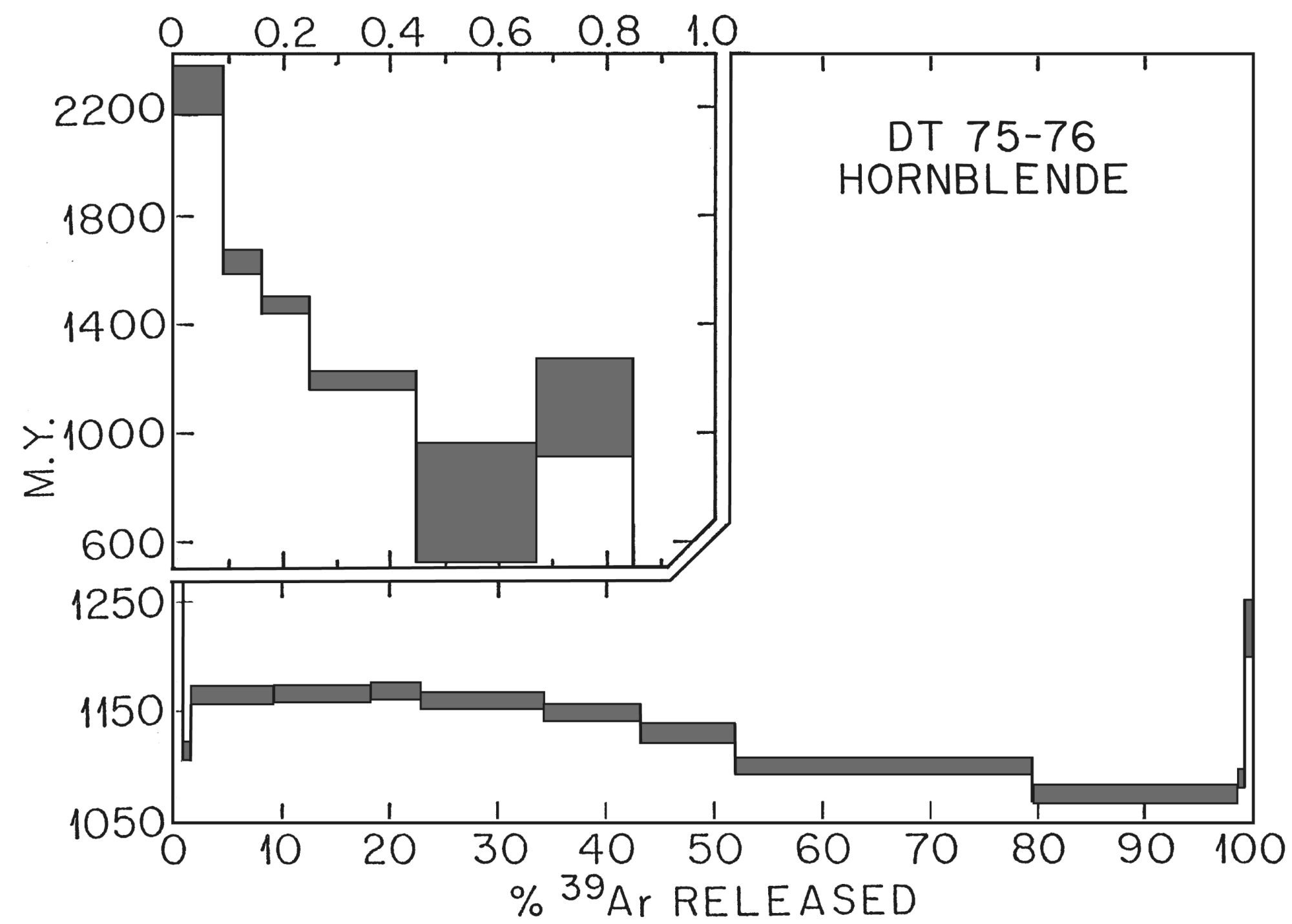

Figure 9. ${ }^{40} \mathrm{Ar} /{ }^{39} \mathrm{Ar}$ age spectrum for DT 75-76 hornblende $\left({ }^{40} \mathrm{Ar} /{ }^{39} \mathrm{Ar}\right.$ total fusion age $\left.1124 \mathrm{Ma}\right)$. High apparent ages in the first three steps $\left(2.26,1.62\right.$, and 1.47 b.y.) may be due to recoil of ${ }^{39} \mathrm{Ar}$ out of the rims of grains during irradiation. The plateau age of 1.16 b.y. probably represents a valid minimum age for the metamorphic recrystallization of the hornblende, but the reason for the anomalous age decrease at the latter part of the spectrum is unclear. 


\section{Rb-Sr Study}

A suite of thirteen $20-\mathrm{kg}$ samples was collected along a 2.5 mile traverse in the Thumb Mountain core zone region of the Kanektok complex for Rb-Sr whole-rock isochron analysis (fig. 3). Analytical work was done by Turner and Hedge at the Denver laboratory of the Branch of Isotope Geology, U.S. Geological Survey. Sample lithologies include garnet amphibolite, biotite amphibolite, hornblende biotite granodiorite gneiss, biotite granodiorite gneiss, biotite quartz monzonite gneiss, biotite granite gneiss, plagioclase-biotite-epidote rock and plagioclase-biotite- muscovite-epidote rock. Results are shown in figure 10 and table 3.

The suite is characterized by low rubidium and relatively high strontium values and the data scatter widely on the ${ }^{87} \mathrm{Sr} /{ }^{86} \mathrm{Sr}$ versus ${ }^{87} \mathrm{Rb} /{ }^{86} \mathrm{Sr}$ diagram (fig. 10). We offer the following speculations regarding the interpretation of these data:

- 1. The six samples that lie on the line determining the lower boundary of the cone of data on the diagram appear to define an isochron age of $1.78 \mathrm{Ga}$. This age agrees with the oldest K-Ar hornblende age and also with the ${ }^{207} \mathrm{~Pb} /{ }^{206} \mathrm{~Pb}$ age of sphene from an orthogneiss body, to be discussed later. This is believed to represent the age of the amphibolite facies metamorphism of the Kanektok terrane.

- 2. Three of the remaining seven samples lie along a line defined by the initial ${ }^{87} \mathrm{Sr} /{ }^{86} \mathrm{Sr}$ ratio and the composite composition point for all thirteen samples. The apparent age of this group is about $2.3 \mathrm{Ga}$. This value is not grossly different from the $\mathrm{U}-\mathrm{Pb}$ age of zircon from the orthogneiss and probably approximates the age of the Kanektok protolith.

- 3. Three additional samples plot far above the composite sample line, in the low-Rb, high- ${ }^{87} \mathrm{Sr} /{ }^{86} \mathrm{Sr}$ area of the diagram. Two of these samples $(97,100)$ are amphibolites that would have had low Rb prior to metamorphism and can be interpreted as having incorporated considerable amounts of ${ }^{87} \mathrm{Sr}$ during the $1.77 \mathrm{Ga}$ metamorphism. This interpretation seems reasonable in view of the fact that these amphibolites are interlayered with biotite-bearing felsic gneisses whose protoliths would be a likely source for the ${ }^{87} \mathrm{Sr}$ during metamorphism. The third sample (88), a biotite granite gneiss, is the most difficult to explain. Such a rock would be expected to be high in both $\mathrm{Rb}$ and ${ }^{87} \mathrm{Sr}$. Its position on the diagram, however, strongly suggests that it has lost a considerable quantity of $\mathrm{Rb}$, an observation which has no obvious explanation. 
Table 3. Analytical data for $\mathrm{Rb}-\mathrm{Sr}$ analyses of whole-rock samples from Kanektok complex core near Thumb Mountain.

\begin{tabular}{|c|c|c|c|c|c|c|c|}
\hline Sample No. & Rock Type & $\underset{{ }^{\circ} \mathbf{N}}{\text { Latitude }}$ & $\begin{array}{c}\text { Longitude } \\
{ }^{\circ} \mathrm{W}\end{array}$ & $\mathbf{R b}(\mathbf{p p m})$ & Sr (ppm) & ${ }^{87} \mathbf{R b} /{ }^{86} \mathrm{Sr}$ & ${ }^{87} \mathrm{Sr} /{ }^{86} \mathrm{Sr}$ \\
\hline DT 75-85 & Garnet amphibolite & 59.6483 & 161.2050 & 20.829 & 155.88 & 0.386897 & 0.711365 \\
\hline DT 75-86 & Quartz monzonite gneiss & 59.6483 & 161.2050 & 91.187 & 555.76 & 0.475359 & 0.717395 \\
\hline DT $75-88$ & Biotite granite gneiss & 59.6450 & 161.1917 & 23.230 & 137.17 & 0.153951 & 0.717476 \\
\hline DT 75-91 & Biotite granodiorite gneiss & 59.6450 & 161.1933 & 92.27 & 889.33 & 0.300363 & 0.709336 \\
\hline DT 75-94 & Plagioclase-biotite-muscovite-epidote rock & 59.6383 & 161.1950 & 54.371 & 435.78 & 0.361275 & 0.711981 \\
\hline DT 75-98 & Garnet amphibolite & 59.6267 & 161.2033 & 21.525 & 261.77 & 0.238006 & 0.707776 \\
\hline DT 75-100 & Garnet epidote amphibolite & 59.6250 & 161.2033 & 7.254 & 262.27 & 0.080063 & 0.708632 \\
\hline DT 75-83-1 & Hornblende biotite granodiorite gneiss & 59.6500 & 161.2083 & 38.627 & 847.33 & 0.131922 & 0.705760 \\
\hline DT 75-97 & Garnet amphibolite & 59.6283 & 161.2033 & 8.4709 & 209.92 & 0.116853 & 0.712313 \\
\hline DT 75-82 & Hornblende biotite granodiorite gneiss & 59.6500 & 161.2100 & 38.873 & 858.63 & 0.1310013 & 0.7047931 \\
\hline DT 75-83-2 & Biotite amphibolite & 59.6500 & 161.2083 & 21.0418 & 390.90 & 0.155775 & 0.705722 \\
\hline DT 75-87 & Biotite granodiorite gneiss & 59.6450 & 161.1917 & 45.708 & 638.65 & 0.207171 & 0.708520 \\
\hline DT 75-92 & Plagioclase-biotite epidote rock & 59.6433 & 161.1933 & 66.309 & 726.90 & 0.264042 & 0.708012 \\
\hline
\end{tabular}




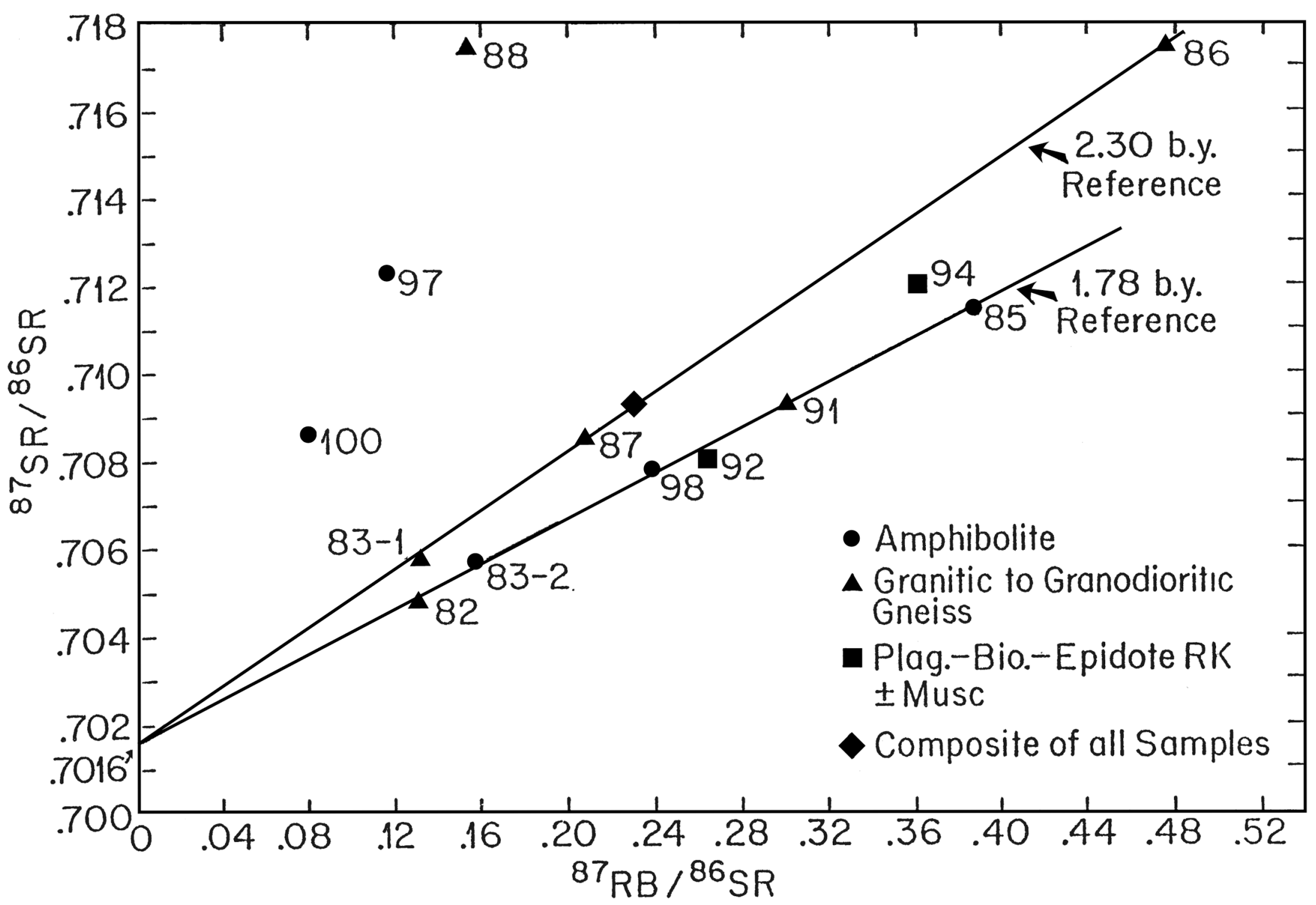

Figure 10. Rb-Sr diagram for 13 whole-rock samples of Kanektok core zone amphibolite facies rocks collected along a 2.5 mile traverse in the Thumb Mountain area (fig. 3). 


\section{U-Th-Pb Results}

Zircon and sphene were separated from an orthogneiss (sample DT 75-86) from the Thumb Mountain core zone area of the Kanektok complex (fig. 3). The gneiss is granitic in composition and is composed primarily of quartz, pink orthoclase and biotite. The zircons are generally euhedral and clear, with length to width ratios of about 3:1. Although some grains are cracked and broken, most appear to have remained idiomorphic.

Standard isotope dilution techniques for $\mathrm{U}$ and $\mathrm{Pb}$ (modified from Krogh, 1973), were performed by Aleinikoff on three size fraction splits of the zircons (table 4). ${ }^{207} \mathrm{~Pb} /{ }^{206} \mathrm{~Pb}$ ages in all three splits are identical $(2.05 \mathrm{Ga})$ and the $\mathrm{Pb} / \mathrm{U}$ ages vary only slightly (from 1,610 to 1,834 Ma). The uranium concentrations, which range from 375 to $414 \mathrm{ppm}$, are fairly low and thus the crystals are not metamict. The low uranium concentrations have caused little damage to the crystal lattices, and therefore, the structures have remained essentially impermeable to leaching fluids until very recent time. A concordia plot (fig. 11) with a best-fit line calculation (Ludwig, 1980) indicates that the orthogneiss protolith crystallized about $2.05 \pm 0.03 \mathrm{Ga}$. Although the rock was subsequently metamorphosed to amphibolite grade, this event is not recorded in the zircon data. Modern lead loss due to dilatancy (Goldich and Mudrey, 1972) has moved the data points down a discordia towards the present.

A sphene fraction from the same sample of orthogneiss was analyzed for $U$, Th, and $\mathrm{Pb}$ isotopes in order to determine the age of metamorphism of the Kanektok complex (table 4). Sphene ages are known to be more susceptible to resetting by thermal metamorphism than are zircon ages, but are more resistant than biotite and hornblende $\mathrm{K}-\mathrm{Ar}$ ages (Hanson and others, 1971). Thus, we interpret the U-Pb data from the sphene as indicating that the amphibolite-grade metamorphism occurred about $1.77 \mathrm{~b} . \mathrm{y}$. ago $\left({ }^{207} \mathrm{~Pb} /{ }^{206} \mathrm{~Pb}\right.$ age $)$. The high $\mathrm{Pb} / \mathrm{Th}$ age cannot be explained on geologic grounds, but may have been caused by loss of some Th during dissolution of the sample in the laboratory.

\section{Summary and Conclusions}

The Kanektok complex of southwestern Alaska appears to be a rootless terrane of early Proterozoic sedimentary, volcanic, and intrusive rocks which were metamorphosed to amphibolite and granulite fades and later underwent a pervasive late Mesozoic thermal event accompanied by granitic plutonism and greenschist facies metamorphism of overlying sediments. Although the terrane exhibits characteristics generally attributed to mantled gneiss domes, field mapping and geophysical studies by Hoare and Coonrad (1979) suggest that the complex is rootless and thrust over much younger rocks. 
Table 4. U, Th, and $\mathrm{Pb}$ isotopic data for zircon and sphene from quartz monzonite orthogneiss near Thumb Mountain. [Sample locality latitude $59^{\circ} 38.9^{\prime} \mathrm{N}$, longitude $161^{\circ} 12.3^{\prime} \mathrm{W}$. * Atomic percent is blank corrected.

${ }^{235} \mathrm{U} /{ }^{238} \mathrm{U}=1 / 137.88, \lambda_{235}=0.98485 \times 10^{-9} / \mathrm{yr}, \lambda_{238}=0.155125 \times 10^{-9} / \mathrm{yr}, \lambda_{232}=0.049475 \times 10^{-9} / \mathrm{yr}$ (Steiger and Jager, 1977 ) $]$

\begin{tabular}{|c|c|c|c|c|c|c|c|c|c|c|c|}
\hline \multirow[b]{2}{*}{ Sample No. } & \multicolumn{3}{|c|}{ Concentration (ppm) } & \multicolumn{4}{|c|}{ Atomic percent* } & \multicolumn{4}{|c|}{ Ages (Ma) } \\
\hline & $\mathbf{U}$ & Th & $\mathbf{P b}$ & ${ }^{204} \mathrm{~Pb}$ & ${ }^{206} \mathrm{~Pb}$ & ${ }^{207} \mathrm{~Pb}$ & ${ }^{208} \mathbf{P b}$ & $\begin{array}{l}{ }^{206} \mathrm{~Pb} / \\
{ }^{238} \mathrm{U}\end{array}$ & $\begin{array}{l}{ }^{207} \mathbf{P b} / \\
{ }^{235} \mathrm{U}\end{array}$ & $\begin{array}{l}{ }^{207} \mathrm{~Pb} / \\
{ }^{235} \mathrm{~Pb}\end{array}$ & ${ }^{208} \mathrm{~Pb} /$ \\
\hline DT 75-86 & & & & & & & & & & & \\
\hline Zircon $(+150)$ & 374.6 & & 116.7 & 0.015 & 78.61 & 10.12 & 11.26 & 1610 & 1808 & 2046 & \\
\hline $\begin{array}{c}\text { Zircon (-150 } \\
+200)\end{array}$ & 402.6 & & 129.0 & 0.006 & 78.59 & 10.00 & 11.40 & 1653 & 1834 & 2046 & \\
\hline Zircon $(-325)$ & 414.2 & & 132.3 & 0.002 & 78.17 & 9.90 & 11.91 & 1642 & 1827 & 2046 & \\
\hline Sphene & 8.4 & 18.6 & 16.6 & 1.075 & 30.43 & 17.97 & 50.52 & 1751 & 1761 & 1774 & 2408 \\
\hline
\end{tabular}




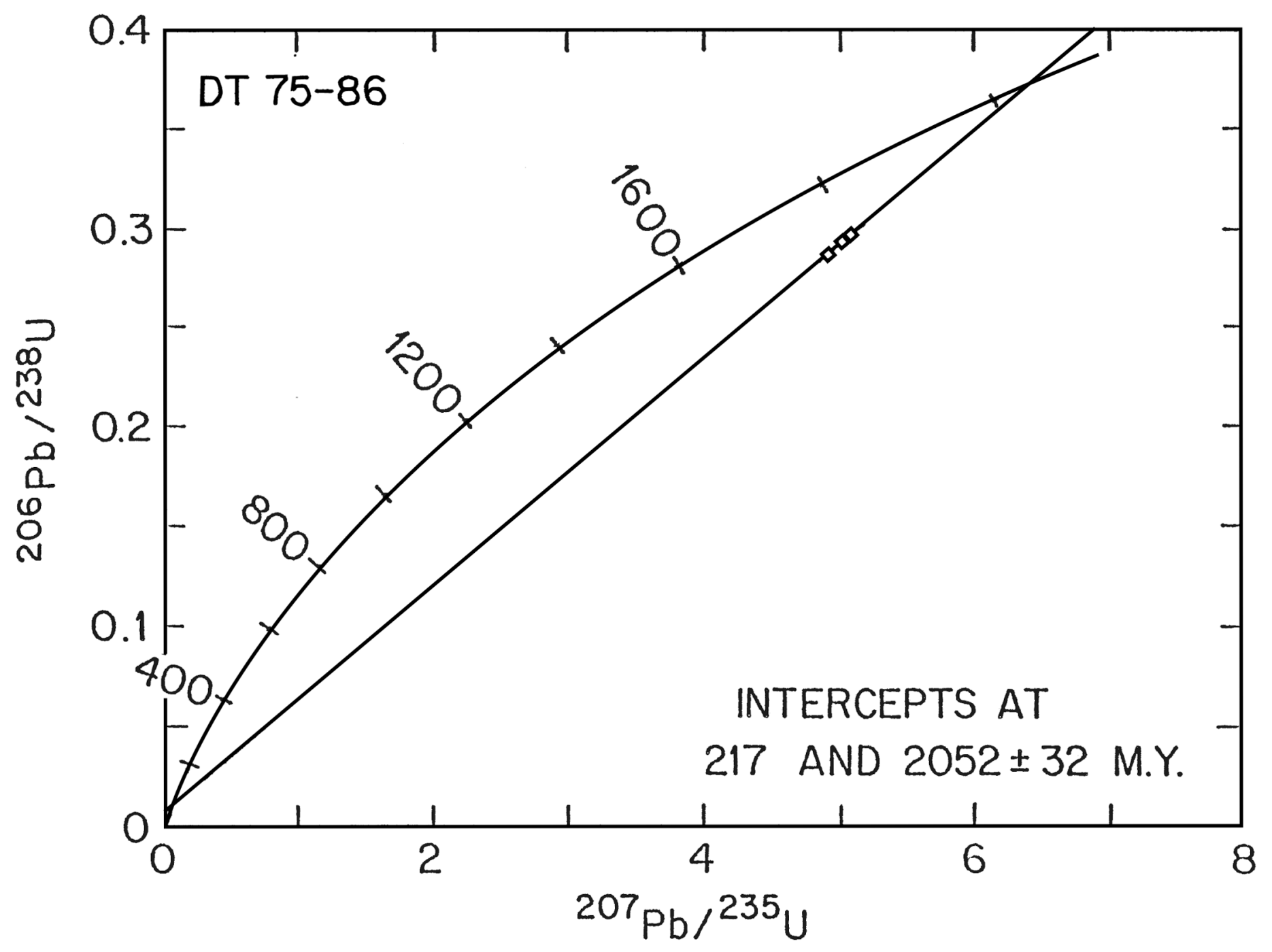

Figure 11. Concordia plot of 3 size fraction splits of zircons from core zone orthogneiss sample DT 75-86 from the Thumb Mountain area (fig. 3). 
The granitic gneisses of the Kanektok complex are assigned an intrusive age of $2.05 \pm 0.03 \mathrm{Ga}$. They were metamorphosed about 1.77 b.y. ago, and have not suffered severe deformation since then. The early Proterozoic age for the protolith of the orthogneisses is similar to recently determined ages from the Yukon-Tanana Upland (Aleinikoff and others, 1981). ${ }^{4}$ Although slightly older ages $(2.1$ to $2.3 \mathrm{Ga})$ are present in the Upland, those ages are mostly derived from detrital zircons in metasediments and plutonic zircons with inheritance. Only one metarhyodacite $(2.1 \mathrm{Ga})$ has been directly dated (Aleinikoff and others, 1986).

A Rb-Sr study of 13 whole-rock samples also suggests metamorphism of an early Proterozoic [Paleoproterozoic] protolith at $1.77 \mathrm{Ga}$, although the data are widely scattered and difficult to interpret. It is clear from the $\mathrm{Rb}-\mathrm{Sr}$ data that $\mathrm{Sr}$ isotopes were not homogenized over the scale of sampling (2.5 miles) during the $1.77 \mathrm{Ga}$ metamorphism.

Analysis of K-Ar mineral ages from 58 rocks indicate that nearly all of these ages have been totally or partially reset by a pervasive late Mesozoic thermal event. Several biotites gave apparent $\mathrm{K}$-Ar ages over $2 \mathrm{Ga}$. These ages appear to be controlled by excess radiogenic ${ }^{40} \mathrm{Ar}$ produced by the degassing protolith during the $1.77 \mathrm{Ga}$ metamorphism and incorporated by the biotites when they were at temperatures at which Ar could diffuse through the lattice.

Five amphibolites yielded apparent Precambrian ${ }^{40} \mathrm{~K} /{ }^{40} \mathrm{Ar}$ ages. There is no evidence that these hornblende ages have been increased by excess argon. The oldest conventional ${ }^{40} \mathrm{~K} /{ }^{40} \mathrm{Ar}$ hornblende age of $1.77 \mathrm{Ga}$ is identical to the sphene ${ }^{207} \mathrm{~Pb} /{ }^{206} \mathrm{~Pb}$ orthogneiss age and to the $\mathrm{Rb}-\mathrm{Sr}$ "isochron" age for six of the 13 whole-rock samples. The younger hornblende ages are interpreted as having been partially reset during the late Mesozoic thermal event. This event is believed to coincide with granitic plutonism and with the greenschist facies metamorphism of the marginal metasediments flanking the core zone of the complex.

${ }^{40} \mathrm{Ar} /{ }^{39} \mathrm{Ar}$ incremental heating experiments suggest metamorphism occurred at least 1.2 b.y. ago but do not exhibit high temperature plateau ages significantly older than the ${ }^{40} \mathrm{Ar} /{ }^{39} \mathrm{Ar}$ total fusion ages of these samples. The age spectra are much more uniform than expected from a terrane with such a complex thermal history. We suspect that this may be an experimental artifact perhaps caused by the fine grain size of the samples which may possibly be less than the effective Ar diffusion radii of the analyzed hornblendes.

The Kanektok complex comprises the Kilbuck tectonostratigraphic terrane of Jones and others (1981). The $1.77 \mathrm{Ga}$ age of its high grade metamorphic rocks is significantly older than nearly all radiometric ages determined thus far for present Alaskan rock units. The age and lithology of this terrane appear to be unique in Alaska. These characteristics should prove useful in tectonic reconstructions aimed at finding the source region for this terrane prior to its migration to its present position in southwestern Alaska.

\footnotetext{
4 The orthogneiss from the Yukon-Tanana Upland that the Turner and others manuscript mentions, citing Aleinikoff and others (1981) is now recognized as a metamorphosed 350 Ma pluton containing inherited zircons (Wilson and others, 1985; Aleinikoff and others, 1986).
} 


\section{Acknowledgments}

Turner wishes to express his appreciation to the Research School of Earth Sciences, Australian National University, and to Dr. Ian McDougall for the use of laboratory facilities and guidance in the ${ }^{40} \mathrm{Ar} /{ }^{39} \mathrm{Ar}$ work, and for partial financial support for this work. The Australian Institute of Nuclear Science and Engineering facilitated the irradiation. He is also indebted to the Isotope Geology Branch of the U.S. Geological Survey in Denver, Colorado, and to Dr. Carl Hedge for use of laboratory facilities and guidance during the $\mathrm{Rb}-\mathrm{Sr}$ work. Kiyoto Futa provided assistance with the $\mathrm{Rb}-\mathrm{Sr}$ analyses. Drs. G. Brent Dalrymple and Marvin Lanphere of the U.S. Geological Survey Menlo Park Isotope Geology Laboratory kindly made facilities available and provided assistance with the earlier ${ }^{40} \mathrm{Ar} /{ }^{39} \mathrm{Ar}$ work.

\section{References Cited}

Aleinikoff, J.N., Dusel-Bacon, Cynthia, and Foster, H.L., 1986, Geochronology of augen gneiss and related rocks, Yukon-Tanana terrane, east-central Alaska: Geological Society of America Bulletin, v. 97, no. 5, p. 626-637.

Aleinikoff, J.N., Dusel-Bacon, Cynthia, Foster, H.L., and Futa, K., 1981, Proterozoic zircon from augen gneiss, Yukon-Tanana Upland, east-central Alaska: Geology, v. 9, p. 469-473.

Aleinikoff, J.N., Foster, H.L., Nokleberg, W.J., and Dusel-Bacon, Cynthia, 1984, Isotopic evidence from detrital zircons for Early Proterozoic crustal material, east-central Alaska, in Coonrad, W.L., and Elliott, R.L., eds., The United States Geological Survey in Alaska-Accomplishments during 1981: U.S. Geological Survey Circular 868, p. 43-45.

Brabb, E.E., and Churkin, M., Jr., 1969, Geologic map of the Charley River quadrangle, east-central Alaska: U.S. Geological Survey Miscellaneous Geologic Investigations Map I-573, scale 1:250,000.

Bunker, C.M., Hedge, C.E., and Sainsbury, C.L., 1977, Radio-element concentrations and preliminary radiometric ages of rocks of the Kigluaik Mountains, Seward Peninsula, Alaska: U.S. Geological Survey Open-File Report 77-735, 36 p.

Churkin, Michael, Jr. and Eberlein, G.D., 1977, Ancient borderland terranes of the North American Cordillera - Their correlation and plate tectonics: Geological Society of America Bulletin, v. 88, p. 776-777.

Dutro, J.T., Jr., Brosgé, W.P., and Reiser, H.M., 1972, Significance of recently discovered Cambrian fossils and reinterpretation of Neruokpuk Formation, northeastern Alaska: American Association of Petroleum Geologists Bulletin, v. 56, p. 808-815.

Goldich, S.S., and Mudrey, M.G., 1972, Dilatancy model for discordant U-Pb ages, in Tugarinov, A., ed., Contributions to recent geochemistry and analytical chemistry, Vinogradov Volume: Moscow USSR Nauk Publ. Office., p. 415-418.

Hanson, G.N., Catanzaro, E.J., and Anderson, D.H., 1971, U-Pb ages for sphene in a contact metamorphic zone: Earth Planetary Science Letters, v. 12, p. 231-237.

Harrison, T.M., and McDougall, Ian, 1980, Investigations of an intrusive contact, northwest Nelson, New Zealand - II. Diffusion of radiogenic and excess ${ }^{40} \mathrm{Ar}$ in hornblende revealed by ${ }^{40} \mathrm{Ar} /{ }^{39} \mathrm{Ar}$ age spectrum analysis: Geochimica et Cosmochimica Acta, v. 44, p. 2005-2020. 
Hoare, J.M., and Coonrad, W.L., 1959, Geology of the Bethel quadrangle, Alaska: U.S. Geological Survey Miscellaneous Geologic Investigations Map I-285, scale $1: 250,000$.

Hoare, J.M., and Coonrad, W.L., 1961, Geologic map of the Goodnews quadrangle, Alaska: U.S. Geological Survey Miscellaneous Geologic Investigations Map I339 , scale $1: 250,000$.

Hoare, J.M., and Coonrad, W.L., 1979, The Kanektok metamorphic complex, a rootless belt of Precambrian rocks in southwestern Alaska, in Johnson, K.M., and Williams, J.R., eds., The U.S. Geological Survey in Alaska-Accomplishments during 1978: U.S. Geological Survey Circular 804-B, p. B72-B74.

Jones, D.L., Silberling, N.J., Berg, H.C., and Plafker, George, 1981, Map showing tectonostratigraphic terranes of Alaska, columnar sections, and summary descriptions of terranes, U.S. Geological Survey Open-File Report 81-792, 20 p., $2 \mathrm{p} 1$.

Krogh, T.E., 1973, A low-contamination method for hydrothermal decomposition of zircon and extraction of $\mathrm{U}$ and $\mathrm{Pb}$ for isotopic age determinations: Geochimica et Cosmochimica Acta, v. 37, p. 485-494.

Lanphere, M.A., and Dalrymple, G.B., 1971, A test of the ${ }^{40} \mathrm{Ar} /{ }^{39} \mathrm{Ar}$ age spectrum technique on some terrestrial materials: Earth Planetary Science Letters, v. 12, p. 359-372.

Lobach-Zuchenko, S.L., Kratz, K.O., Gerlirig, E.K., Gorokhov, I.M., Koltsova, T.V., Morozova, I.M., Krylov, I.N., Gekulaev, V.P., Puskarev, I.D., Sprintsov, V.D., and Alferovskii, A.A., 1972, Geochronological constraints for the evolution of the Baltic Shield: Leningrad, Akad. Nauk S.S.R., p. 1-193.

Ludwig, K.R., 1980, Calculation of uncertainties of U-Pb isotope data: Earth Planetary Science Letters, v. 46, p. 212-220.

Mayfield, C.F., Silberman, M.L., and Tailleur, I.L., 1982, Precambrian metamorphic rocks from the Hub Mountain terrane, Baird Mountains quadrangle, Alaska, in Coonrad, W.L., ed., The United States Geological Survey in AlaskaAccomplishments during 1980: U.S. Geological Survey Circular 844, p. 18-22.

Mertie, J.B., Jr., 1937, The Yukon-Tanana region, Alaska: U.S. Geological Survey Bulletin 872, $276 \mathrm{p}$.

Pankhurst, R.J., Moorbath, S., Rex D.C., and Turner, G., 1973, Mineral age patterns in ca 3700 m.y. old rocks from west Greenland: Earth Planetary Science Letters, v. 20, p. $157-170$.

Spurr, J.E., 1898, Geology of the Yukon gold district, Alaska: U.S. Geological Survey, 18th Annual Report, pt. 3, p. 87-392.

Steiger, R.H., and Jager, E., 1977, Subcommission on geochronology-convention on the use of decay constants in geo- and cosmochronology: Earth Planetary Science Letters, v. 36, p. 359-362.

Tetley, N.W., 1978, Geochronology by the ${ }^{40} \mathrm{Ar} /{ }^{39} \mathrm{Ar}$ technique using HIFAR reactor: Canberra, Australian National University, Research School of Earth Sciences, Ph.D. dissertation, 287 p. and appendices.

Turner, D.L., Forbes, R.B., and Dillon, J.T., 1979, K-Ar geochronology of the southwestern Brooks Range, Alaska: Canadian Journal of Earth Sciences, v. 16, no. 9, p. 1789-1804.

Wilson, F.H., Smith, J.G., and Shew, N., 1985, Review of radiometric data from the Yukon crystalline terrane, Alaska and Yukon Territory: Canadian Journal of Earth Sciences, v. 22, p. 525-537. 